\title{
Evaluation and projection of mean surface temperature using CMIP6 models over East Africa
}

Brian Ayugi ${ }^{1,2^{*}}$, Hamida Ngoma ${ }^{2,4}$, Hassen Babaousmail ${ }^{3}$, Rizwan Karim ${ }^{2}$, Vedaste Iyakaremye $^{2,5}$, Kenny T.C. Lim Kam Sian ${ }^{3,2}$, Victor Ongoma ${ }^{6}$

${ }^{1}$ Jiangsu Key Laboratory of Atmospheric Environment Monitoring and Pollution Control, Collab orative Innovation Center of Atmospheric Environment and Equipment Technology, School of En vironmental Science and Engineering, Nanjing University of Information Science and Technolog y, Nanjing 210044, China

${ }^{2}$ Key Laboratory of Meteorological Disaster, Ministry of Education (KLME)/Joint International Research Laboratory of Climate and Environment Change (ILCEC)/Collaborative Innovation Center on Forecast and Evaluation of Meteorological Disasters (CIC-FEMD), Nanjing University of Information Science and Technology, Nanjing 210044, China

${ }^{3}$ Binjiang College of Nanjing University of Information Science and Technology, Jiangsu, Wuxi, China

${ }^{4}$ Makerere University, Department of Geography, Geoinformatics and Climatic Sciences, P.O. Box 7062 Kampala Uganda

${ }^{5}$ Rwanda Meteorology Agency, Kigali, Rwanda

${ }^{6}$ International Water Research Institute, Mohammed VI Polytechnic University, Lot 660, Hay Moulay Rachid, Ben Guerir, 43150, Morocco

*Corresponding author: ayugi.o@gmail.com

\begin{abstract}
This study evaluates the historical mean surface temperature (hereafter T2m) and examines how T2m changes over East Africa (EA) in the $21^{\text {st }}$ century using CMIP6 models. An evaluation was conducted based on mean state, trends, and statistical metrics (Bias, Correlation Coefficient, Root Mean Square Difference, and Taylor skill score). For future projections over EA, five best performing CMIP6 models (based on their performance ranking in historical mean temperature
\end{abstract}


simulations) under the shared socioeconomic pathways SSP2-4.5 and SSP5-8.5 scenarios were employed. The historical simulations reveal an overestimation of the mean annual T2m cycle over the study region with fewer models depicting underestimations. Further, CMIP6 models reproduce the spatial and temporal trends within the observed range proximity. Overall, the best performing models are as follows: FGOALS-g3, HadGEM-GC31-LL, MPI-ESM2-LR, CNRM-CM6-1, and IPSL-CM6A-LR. During the three-time slice under consideration, the Multi Model Ensemble (MME) project many changes during the late period $(2080-2100)$ with expected mean changes at $2.4{ }^{\circ} \mathrm{C}$ for SSP2-4.5 and $4.4{ }^{\circ} \mathrm{C}$ for the SSP5-8.5 scenario. The magnitude of change based on Sen's slope estimator and Mann-Kendall test reveal significant increasing tendencies with projections of $0.24^{\circ} \mathrm{C}$ decade- $1\left(0.65^{\circ} \mathrm{C}\right.$ decade-1) under SSP2-4.5 (SSP5-8.5) scenarios. The findings from this study illustrate higher warming in the latest model outputs of CMIP6 relative to its predecessor, despite identical instantaneous radiative forcing.

Keywords: Mean surface temperature, CMIP6, evaluation, projections, East Africa

\section{Introduction}

The global mean surface temperature (GMST) records continue to set new levels year after year from 2011 to present (IPCC, 2018; WMO, 2020). Despite the global impacts of coronavirus disease (COVID-19), the year 2020 stood to be the warmest year, with new records set to about $1.2{ }^{\circ} \mathrm{C}$ above the pre-industrial $(1850$ - 1900) level (WMO, 2020). The situation is further exacerbated with the recent report highlighting an alarming tendency of GMST warming at 0.1 0.3 per decade, which continue to have an adverse impact on human and ecosystem (IPCC, 2018). Comparative analysis before and after the 1950s reveals an amplification of extreme events resulting from heightened warming of global land and ocean (IPCC, 2014). Efforts to mitigate the impacts of global warming levels (GWLs) to below $2{ }^{\circ} \mathrm{C}$ or even much more preferred targets of $1.5^{\circ} \mathrm{C}$ under current greenhouse levels (GHGs) remains an elusive ambition despite the efforts by United Nations Framework Convention on Climate Change (UNFCCC) Paris Agreement (UNFCCC, 2015). In order to stabilize the GMST from further upward trajectories, concerted energies from all stakeholders will be required to devise appropriate and urgent actions to guide the earth system from crossing the threshold to the worst-case scenario of "Hothouse Earth" (Steffen et al., 2018). 
The scientific community plays a critical role in providing timely and accurate information regarding the evolution of climate anomalies that currently define the present world and the future frequencies. The advent of the Coupled Model Intercomparison Project (CMIP) has significantly aided in understanding the projected patterns of the climate system. The resultant advancement is the General Circulation Models (GCMs), capable of enhancing our understanding of the climate system. The output of these models informs relevant stakeholders on the formulation of effective and sustainable policies.

The recent model outputs of CMIP6 promise to exemplify the most accurate projections of future climate due to the massive improvements compared to previous outputs (Eyring et al., 2016). To illustrate this, higher spatial resolution $(\sim 70 \mathrm{~km})$ in comparison to coarser resolution $(\sim$ $250 \mathrm{~km}$ ) for CMIP5 characterizes the current model generation. Besides, improved physical processes and biogeochemical cycles, new features such as improved aerosols' effect or refined parameterization schemes, assorted range of socioeconomic pathways (SSPs; van Vuuren et al., 2014; O’Neill et al., 2017), and large ensemble members are among the developments that describe the latest model outputs. Subsequently, large volumes of research outputs based on CMIP6 have highlighted notable improvements in modelling various aspects of the climate system or comparative analysis of the added value in CMIP6 as compared to CMIP5 (Voldoire et al., 2019; Mauritsen et al., 2019; Hajima et al., 2020; Moseid et al., 2020). Studies focusing on simulations or projection of mean and extreme climate based on CMIP6 (e.g., Akinsanola et al., 2020; Almazroui et al., 2020a, b; Grose et al., 2020; Jiang et al., 2020) or comparative studies of CMIP6 against CMIP5 performance have also reported better and more reliable results (Gusain et al., 2020; Jiang et al., 2020; Luo et al., 2020; Nie et al., 2020; Senevirante and Hauser, 2020; Zamani et al., 2020; Zhu et al., 2020). Remarkably, these studies continue to enhance our understanding of the suitable models to be employed for accurate diagnosis and projection of impact analysis.

Over East Africa (Figure. 1), the livelihood of a population that is mainly dependent on climate variables is under threat posed by pronounced changes in the climate system, mainly due to an increase in T2m and reduced precipitation (Shongwe et al., 2011; Senevirante et al., 2012; Niang et al., 2014; Ongoma et al., 2018; Ayugi and Tan, 2019; Gebrechorkos et al., 2019). The damages witnessed over recent years is threatening the economy and ecosystem (IPCC, 2014). For instance, recurrent droughts (Nicholson, 2014; Haile et al., 2019; Tan et al., 2020) and floods (Kilavi et al., 2018; Juma et al., 2020) remain the signature features affecting millions of people 
and has a negative impact on the gross domestic product in the region that is mainly dependent on the agrarian economy (World Bank, 2012; FAO, 2019). Characterizing observed events has been based on various reanalysis or gauge-based estimates that have pointed clear historical patterns and vulnerable regions identified (Liebman et al., 2014; Lyon, 2014; Gebremeskel et al., 2019). However, future projection studies of $\mathrm{T} 2 \mathrm{~m}$ and precipitation climate have been conducted using the available GCMs from CMIP3/5 (Shongwe et al., 2011; Otieno and Anyah, 2013a, b; Ongoma et al., 2018a, 2018b) or dynamically downscaled regional datasets (RCMs) (Osima et al., 2018; Ayugi et al., 2020; Onyutha, 2020; Ogega et al., 2020). Undoubtedly, these "studies' overall conclusion shows a varying change trend, mainly attributed to the datasets employed or period analyzed.

At present, few studies have been conducted using the latest model output to clearly delineate the local changes in climate features that keep evolving with new challenges due to the steady rise in greenhouse gas (GHGs) emissions. Existing studies based on previous CMIPs versions or regionally downscaled models under the CORDEX framework have documented the spatial and temporal variance, trends, extreme occurrences, and possible projections with respective attributes highlighted (IPCC, 2001; Collins et al., 2011; IPCC, 2014; Omondi et al., 2014; Camberlin, 2017; Ongoma and Chen, 2017; Ongoma et al., 2018a; Gebrechorkos et al., 2018; Osima et al., 2018; Ayugi and Tan, 2019). The aforementioned studies have pointed to an increase in $\mathrm{T} 2 \mathrm{~m}$, trends, and increase (decrease) in observed maximum (minimum) temperatures. The observed changes have a massive impact on the wellbeing of society and ecosystems services. For instance, temperature changes have resulted in an increase in malaria infestations (Omumbo et al., 2011), lowered food production (Lyon, 2014; Adhakari et al., 2015; Mumo et al., 2018; Ayugi et al., 2020a), and recurring pest and diseases outbreak (Walther et al., 2012; Rosenzweig et al., 2014).

In order to provide the latest information regarding the possible future scenarios based on CMIP6 models, there is a need to establish suitable models capable of reproducing local climate and provide accurate simulations (Flato et al., 2013; Sillman et al., 2013). As a basis to identify the most suitable models for climate projections, this study evaluates the historical T2m using an observational gauge product from the climatic research unit (CRU TS4.03; Harris, 2020) and examines how T2m will change in the $21^{\text {st }}$ century. The suitability and reliability of the observed datasets have been proven in several studies over the study domain (Ogwang et al., 2015; Ayugi 
et al., 2016; Ongoma and Chen, 2017; Karendi et al., 2017). The rest of the paper is organized as follows: Section 2 presents the study area, data, and techniques employed, while section 3 gives the results and discussions. Finally, section 4 highlights the critical conclusion and future recommendations for further studies.

\section{Data Methods}

\subsection{Study Area}

Figure 1 shows the study area, demarcated within the geographical coordinate of longitude $28^{\circ} \mathrm{E}$ $-40^{\circ} \mathrm{E}$ and latitude $12^{\circ} \mathrm{S}-5^{\circ} \mathrm{N}$. The region is situated on the eastern belt of the African continent and mostly referred to as East Africa (EA), and is composed of five countries, namely Kenya, Uganda, Tanzania, Burundi, and Rwanda. Intricate landscape features such as Mt. Kilimanjaro, Mt. Elgon, Mt. Kenya, Mt. Rwenzori, Lake Victoria, a large expanse of arid and semi-arid lands (ASALs), and highland regions depict fluctuations of temperature from one region to another (Graffiths, 1972; Camberlin, 2018). However, the standard deviation (SD) of mean annual and seasonal temperatures is minimal, with a maximum variation of $2^{\circ} \mathrm{C}<\mathrm{SD}<5^{\circ} \mathrm{C}$ experienced. For instance, the lowest temperature range is noted in the region along the equator from western Kenya through southern Uganda, Burundi and Rwanda. Conversely, the highest temperature is experienced over the ASALs regions located over eastern Kenya, northwest/east Kenya and northern Uganda, with maximum temperature occurring throughout the year, mainly attributed to lack of cloud and vegetation cover (Pepin et al., 2014). Annual climatology of temperature range between $5^{\circ} \mathrm{C}$ to $35^{\circ} \mathrm{C}$ while seasonal temperatures occur during December - February (DJF) and June - August (JJA), representing the highest (lowest) temperature (Daron, 2014; Ongoma et al., 2017; Ayugi and Tan, 2019). 


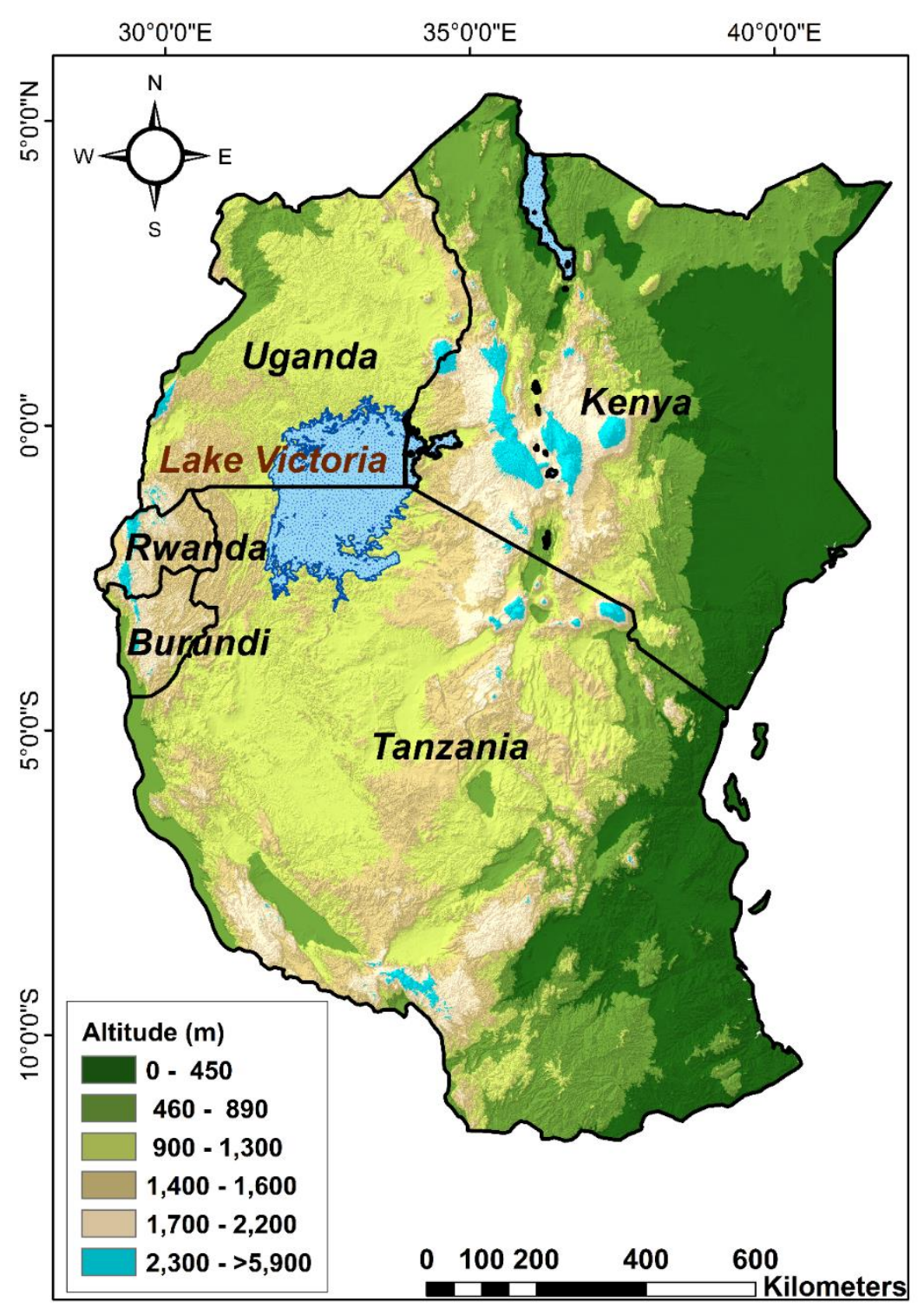

Figure 1. Study area defined within the geographical coordinates [longitude $28^{\circ} \mathrm{E}-40^{\circ} \mathrm{E}$; latitude $\left.12^{\circ} \mathrm{S}-5^{\circ} \mathrm{N}\right]$. In this study, we define East Africa (EA) as a region mainly composed of five countries, namely, Kenya, Uganda, Tanzania, Burundi, and Rwanda. The elevation is shown in $[\mathrm{m}]$.

\subsection{Data and methods}

\subsubsection{Historical Datasets and Analysis}

The study employed thirteen historical models (Table 1) for assessment studies over East Africa. The surface temperature (tas) datasets were retrieved from the CMIP6 repository (https://esgfnode.llnl.gov/search/cmip6). The first realization (r1i1p1f1) for each model members were 
considered for all timescales. The models at each timescale were first standardized for unit and calendar date formats. The standardized datasets were then re-gridded to a common grid of lowest model resolution by utilizing the nearest neighbor interpolation technique. The aforementioned technique interpolation follows the better classification of diverse geography by triangulating nearest points and sub-regionalization of grid points by the nearest cell center of input grids (Mallika et al., 2015; Vermeulen et al., 2017).

All re-gridded models were sliced to the 1970 - 2014 time period for plotting and further analysis. The annual scale multi-model ensemble (MME) for the historical timeline (1970-2014) was developed from the thirteen models. The MMEs reduce biases by canceling them out partly (Pincus et al., 2008); and distinguish the forced signal and natural variability by averaging the spread in natural variability (Eyring et al., 2016). The CRU TS4.03 (Harris et al., 2020) mean temperature dataset for 1970 - 2014 was utilized for benchmarking the models' and MME's performance in simulating annual mean temperature over the study area.

At first, the simulated spatio-temporal climatology for annual mean temperature, MME and CRU datasets were plotted for historical timescale. The temporal anomalies for all datasets were also plotted to observe variability in mean temperature. The performance of models and MME in simulating annual mean temperature against the benchmark CRU was assessed using bias, root mean square difference (RMSD), and correlation coefficient (CC). Mathematical equations for the mentioned metrics are given in(Ayugi et al., 2020; Babaousmail et al., 2019; Ongoma et al., 2019; Ngoma et al., 2021):

$$
\begin{aligned}
& B=\frac{1}{n} \sum_{k=1}^{n}\left(M_{i}-C R U_{i}\right) \\
& R M S E=\sqrt{\frac{1}{n} \sum_{k=1}^{n}\left(M_{i}-C R U_{i}\right)^{2}} \\
& C C=\frac{\sum_{k=1}^{n}\left(C R U_{i}-\overline{O_{l}}\right)\left(M_{i}-\overline{M_{l}}\right)}{\sqrt{\sum_{k=1}^{n}(C R U i-\overline{C R U l})^{2}} \sum_{k=1}^{n}\left(M_{i}-\overline{C R U M_{l}}\right)^{2}}
\end{aligned}
$$

where $M$ identifies the model simulation, CRU refers to observed values, $i$ refer to observed and simulated pairs, and $n$ stands for a total number of pairs in a time series. Trend analysis provides the spatio-temporal progressions of the changes and variability in a variable or phenomenon. The modified Mann-Kendall (m-MK) trend test (Kendall, 1975; Mann, 1945; Hamed and Rao, 1998) 
was utilized to detect the significance of spatio-temporal trends over East Africa. The magnitude of trends was measured by the Theil and Sen's Slope estimation technique (Sen, 1968). The mentioned method exempts datasets from normal distribution requirements, non-missing values, and no outliers in a time series. Several studies (Ayugi et al., 2018; Ayugi and Tan, 2019; Mumo et al., 2019; Karim et al., 2020; Tadeyo et al., 2020; Ngoma et al., 2021a, b) have followed the trend test and estimation technique in trend analysis.

Further, models were ranked as per their performance using the Taylor diagram. The Taylor diagram coherently compares and represents the variation of the correlation coefficient (CC), and root mean square difference (RMSD) terms in a single diagram (Taylor, 2001). The Taylor skill score (TSS) summarized from the Taylor diagram was used to rank models:

$\mathrm{TSS}=\frac{4\left(1+\mathrm{R}_{m}\right)^{2}}{\left(\frac{\sigma_{m}}{\sigma_{o}}+\frac{\sigma_{o}}{\sigma_{m}}\right)\left(1+\mathrm{R}_{0}\right)^{2}}$

where $\mathrm{R}_{m}$ identify spatial correlation coefficient between the model and observation, $\mathrm{R}_{o}$ is the maximum correlation coefficient $(0.999), \sigma_{m}$ is standard deviation of models' spatial patterns extracted and $\sigma_{o}$ identify the observed spatial patterns for annual mean temperature. A dataset with TSS value near to 1 is considered as the best performing. 
Table 1. Details of the selected CMIP6 models employed in the present study (i.e., model name, institution, and atmospheric resolution).

\begin{tabular}{|c|c|c|c|c|}
\hline No & Models & Institution & Resolution & Reference \\
\hline 1 & CanESM5 & $\begin{array}{l}\text { Canadian Centre for Climate Modelling and } \\
\text { Analysis, Environment and Climate Change } \\
\text { Canada, Victoria, Canada }\end{array}$ & $2.81^{\circ} \times 2.81^{\circ}$ & Swart et al., 2019 \\
\hline 2 & CESM2 & $\begin{array}{l}\text { National Center for Atmospheric Research, } \\
\text { USA }\end{array}$ & $1.25^{\circ} \times 0.94^{\circ}$ & $\begin{array}{l}\text { Danabasoglu et } \\
\text { al., } 2019\end{array}$ \\
\hline 3 & $\begin{array}{l}\text { CESM2- } \\
\text { WACCM }\end{array}$ & $\begin{array}{l}\text { National Center for Atmospheric Research, } \\
\text { USA }\end{array}$ & $1.25^{\circ} \times 0.94^{\circ}$ & $\begin{array}{l}\text { Danabasoglu et } \\
\text { al., } 2019\end{array}$ \\
\hline 4 & CNRM-CM6-1 & $\begin{array}{l}\text { Centre National de } \\
\text { Meteorologiques (France) }\end{array}$ & $1.4^{\circ} \times 1.4^{\circ}$ & $\begin{array}{l}\text { Voldoire et al., } \\
2019\end{array}$ \\
\hline 5 & $\begin{array}{l}\text { CNRM-ESM2- } \\
1\end{array}$ & $\begin{array}{l}\text { Centre National de Recherches } \\
\text { Meteorologiques, Toulouse, France }\end{array}$ & $1.41^{\circ} \times 1.41^{\circ}$ & $\begin{array}{l}\text { Séférian et al., } \\
2019\end{array}$ \\
\hline 6 & FGOALS-g3 & University of Chinese Academy of Sciences & $2^{\circ} \times 2.3^{\circ}$ & $\begin{array}{l}\text { EC-EARTH, } \\
\text { 2019a }\end{array}$ \\
\hline 7 & GFDL-CM4 & $\begin{array}{l}\text { Geophysical Fluid Dynamics Laboratory } \\
\text { (GFDL), USA }\end{array}$ & $2.50 \times 2.00$ & Guo et al., 2018 \\
\hline 8 & $\begin{array}{l}\text { HadGEM- } \\
\text { GC3-1-LL }\end{array}$ & Met Office Hadley Centre & $2.5^{\circ} \times 2.5^{\circ}$ & $\begin{array}{l}\text { Roberts and } \\
\text { Malcolm, } 2017\end{array}$ \\
\hline 9 & $\begin{array}{l}\text { IPSL-CM6A- } \\
\text { LR }\end{array}$ & Institut Pierre Simon Laplace, Paris, France & $2.50^{\circ} \times 1.26^{\circ}$ & $\begin{array}{l}\text { Boucher et al., } \\
2018\end{array}$ \\
\hline 10 & MIROC6 & $\begin{array}{l}\text { National Institute for Environmental Studies, } \\
\text { and Japan Agency for Marine-Earth Science and } \\
\text { Technology (MIROC), Japan }\end{array}$ & $1.4 \times 1.4$ & $\begin{array}{l}\text { Tatebe et al., } \\
2018\end{array}$ \\
\hline 11 & MRI-ESM2-0 & Meteorological Research Institute (MRI), Japan & $1.13^{\circ} \times 1.13^{\circ}$ & $\begin{array}{l}\text { Yukimoto et al., } \\
2019\end{array}$ \\
\hline 12 & $\begin{array}{l}\text { MPI-ESM1-2- } \\
\text { HR }\end{array}$ & $\begin{array}{l}\text { Max Planck Institute for Meteorology } \\
\text { (Germany) }\end{array}$ & $0.9^{\circ} \times 0.9^{\circ}$ & Park et al. (2019) \\
\hline 13 & $\begin{array}{l}\text { MPI-ESM1-2- } \\
\text { LR }\end{array}$ & $\begin{array}{l}\text { Max Planck Institute for Meteorology } \\
\text { (Germany) }\end{array}$ & $1.9^{\circ} \times 1.9^{\circ}$ & Tang et al (2019) \\
\hline
\end{tabular}

\subsubsection{Future projection datasets and data analysis}

For future projections over EA, five best performing CMIP6 models (based on their performance ranking in historical mean temperature simulations) under the shared socioeconomic pathways SSP2-4.5 and SSP5-8.5 scenarios were employed. The models are FGOALS-g3, HadGEM-GC31- 
LL, MPI-ESM2-LR, CNRM-CM6-1, and IPSL-CM6A-LR. The first realization members (r1i1p1f1) of models for both SSP scenarios were chosen for projections. At first, all models for each SSP scenario were standardized for unit scale and calendar date formats and then re-gridded to a common grid resolution following the previously mentioned approaches. In order to follow variations in temperature projections, the whole period was divided into the near-term (2020 2049), mid-term (2050 - 2079), and long-term (2080 - 2100) periods of the $21^{\text {st }}$ century, relative to the historical period of 1985 - 2014. Consequently, the multimodel ensembles (MME) for both SSP scenarios in the near-, mid-, and long-term future were developed for the analysis. Numerous studies agree on the use of MME in providing robust projections of future climate due to the reduction of inherent biases in individual models (Palmer et al., 2005; Miao et al., 2014; Kim et al., 2015; Ahmed et al., 2019). Future spatio-temporal annual T2m changes and uncertainties over EA were calculated by subtracting the near-term, mid-term, and long-term future MME annual mean temperature values from the historical (1985 - 2014) MME annual mean value over the whole region. Besides, the spatio-temporal trends and the significance were calculated using previously mentioned statistical techniques. A number of studies have employed a similar approach to verify the robustness of the moddels in characterizing climatic trends over diverse regions (Ongoma et al., 2020; Tadeyo et al., 2020; Karim et al., 2020). This study also focused on uncertainties in the projections of mean temperature and quantify them in the form of probability density function (PDF). The PDF has an integral function, applied to continuous random variables of multiple intervals, and in return gives the chance of occurrences for values in the intervals (Harris et al., 2006).

\section{Results and Discussions}

\subsection{Evaluation of model performance}

This study examined the capability of CMIP6 models in reproducing the observed T2m as detected by CRU. Eyring et al. (2019) recommends that appropriate model evaluation entails performance metrics for mean state, trends, variability, and key physical processes and possible emergent constraint. In the present study, evaluation of $\mathrm{T} 2 \mathrm{~m}$ was conducted based on mean state, trends, bias, CC, RMSE and Taylor skill score. Figure 2 shows the performance of 13 CMIP6 models and the mean ensemble in reproducing the observed $\mathrm{T} 2 \mathrm{~m}$. The climate models underestimate the observed variable when it simulates lower than detected values, while overestimation is recorded 
when higher than observed patterns is depicted. The CRU data depicted the lowest annual temperature occurring during June to August (JJA), while the highest temperature is noted during January to March (JFM). The highest (lowest) observed temperature is $24.4{ }^{\circ} \mathrm{C}\left(21.3{ }^{\circ} \mathrm{C}\right)$ during March (June) for 1970 - 2014. This is mainly attributed to the variation of the Inter-Tropical Convergence Zone (ITCZ) (Ogallo, 1993; Anyah et al., 2006; Ongoma et al., 2017; Ayugi and Tan, 2019). The lowest temperatures during JJA are a result of cold airmass advected from the south Indian Ocean, featured by Mascarenes High, which enhances the observed low temperature (Ogwang et al., 2015). Consequently, the model Ensemble, MPI - ESM1-2LR, CanESM5, FGOALS-g3, CNRM-CM6-1, and HadGEM-GC31-LL show consistent pattern with the observed data. Conversely, MIROC6 demonstrated a large warm bias with strong overestimations during August, September and October.

The models IPSL-CM6A-LR, and GFDL-CM4 underestimated the observed T2m over the study domain. Most models show an overestimation of the mean annual T2m cycle over the study region, with fewer models depicting underestimations. The GCMs performance over EA region is consistent with other studies that have shown stronger warming as compared to the observed value (Hausfather, 2019; Tokarska et al., 2020). The study attributes the overestimations by most GCMs to equilibrium climate sensitivity that demonstrate higher values in most CMIP6 models outputs. Other studies points to the changes in the forcing data employed that play an important role, particularly the described concentrations of GHGs utilized to force the models (Wyser et al., 2020; Forster et al., 2020; Zelinka et al., 2020; Parsons et al., 2020). 

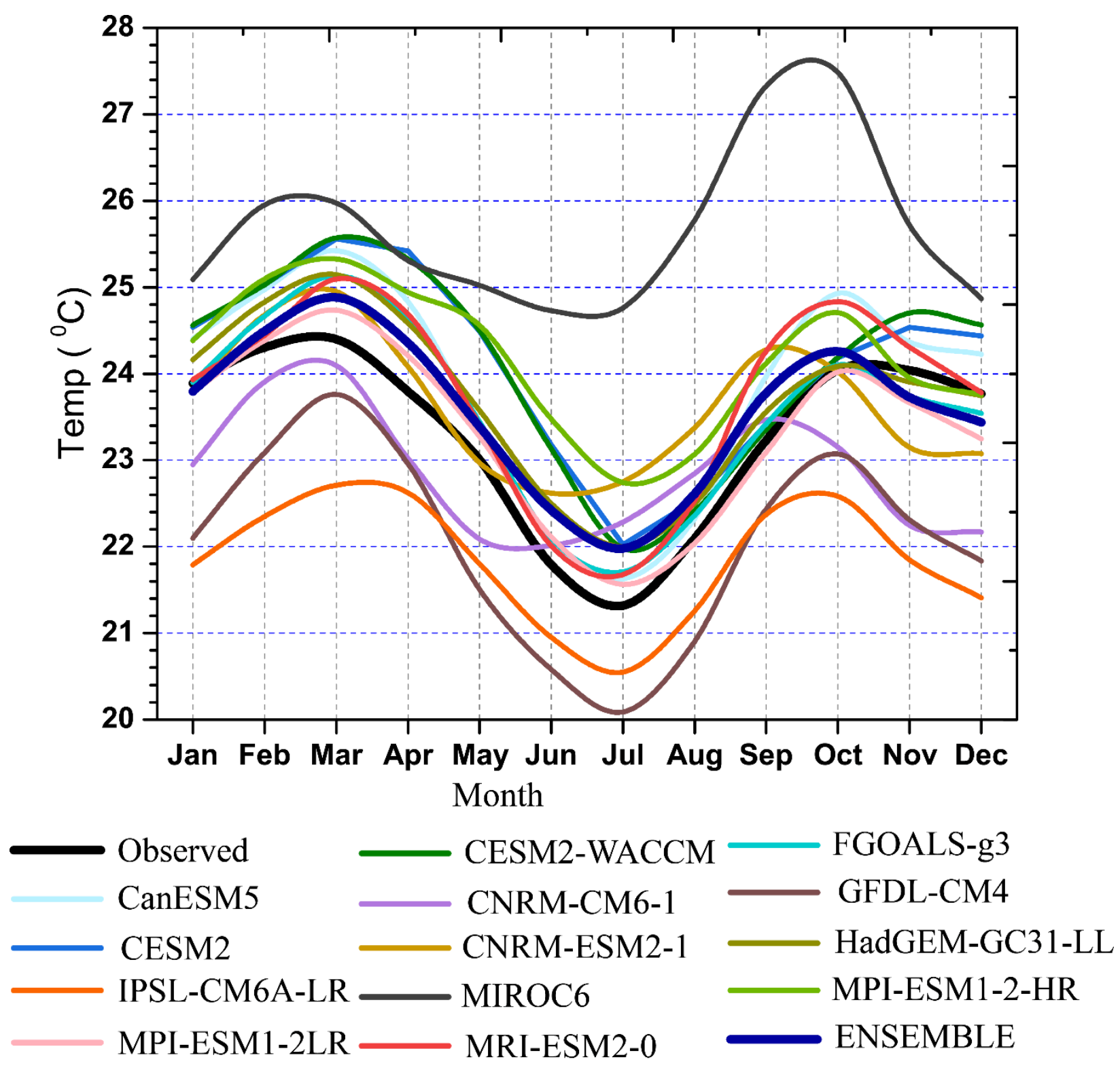

Figure 2. Annual cycle of monthly temperature during 1970 - 2014 based on CRU, and individual CMIP6 GCMs over EA region.

In order to assess the models' capability in reproducing the spatial variance, the mean T2m bias is computed as shown in Figure 3. The models show better performance if the simulated bias is close or equal to zero. Models that show higher (lower) values tend to over (under) estimate the temperature patterns. Overall, the majority of the models are able to depict the climatological temperature patterns of the study region. Nearly all models demonstrate an underestimation in regions with a complex topography and over most regions of Uganda. CanESM5 shows an underestimation by more than $-6.5^{\circ} \mathrm{C}$ over Mount Kenya region. Contrarywise, warm bias is noted 
in MIROC6 model, which is more pronounced over eastern Kenya. The mentioned region is characterized by vast ASALs, thereby experiencing high radiation due to less cloud cover. The model MPI-ESM1-2-HR, on the other hand, show pronounced cold bias over the entire domain. The models FGOALS-g3, CNRM-CM6-1, GFDL-CM4, IPSL-CM6a-LR, and ensemble demonstrate an agreeable pattern, similar to the observed variance. The listed models have a minimal bias of $1.5<$ bias $<-1.5$. The pronounced cold bias over the western sides of the region could be attributed to the vast vegetation cover and presence of most mountains and highlands, which has an influence on the local temperature variation. 

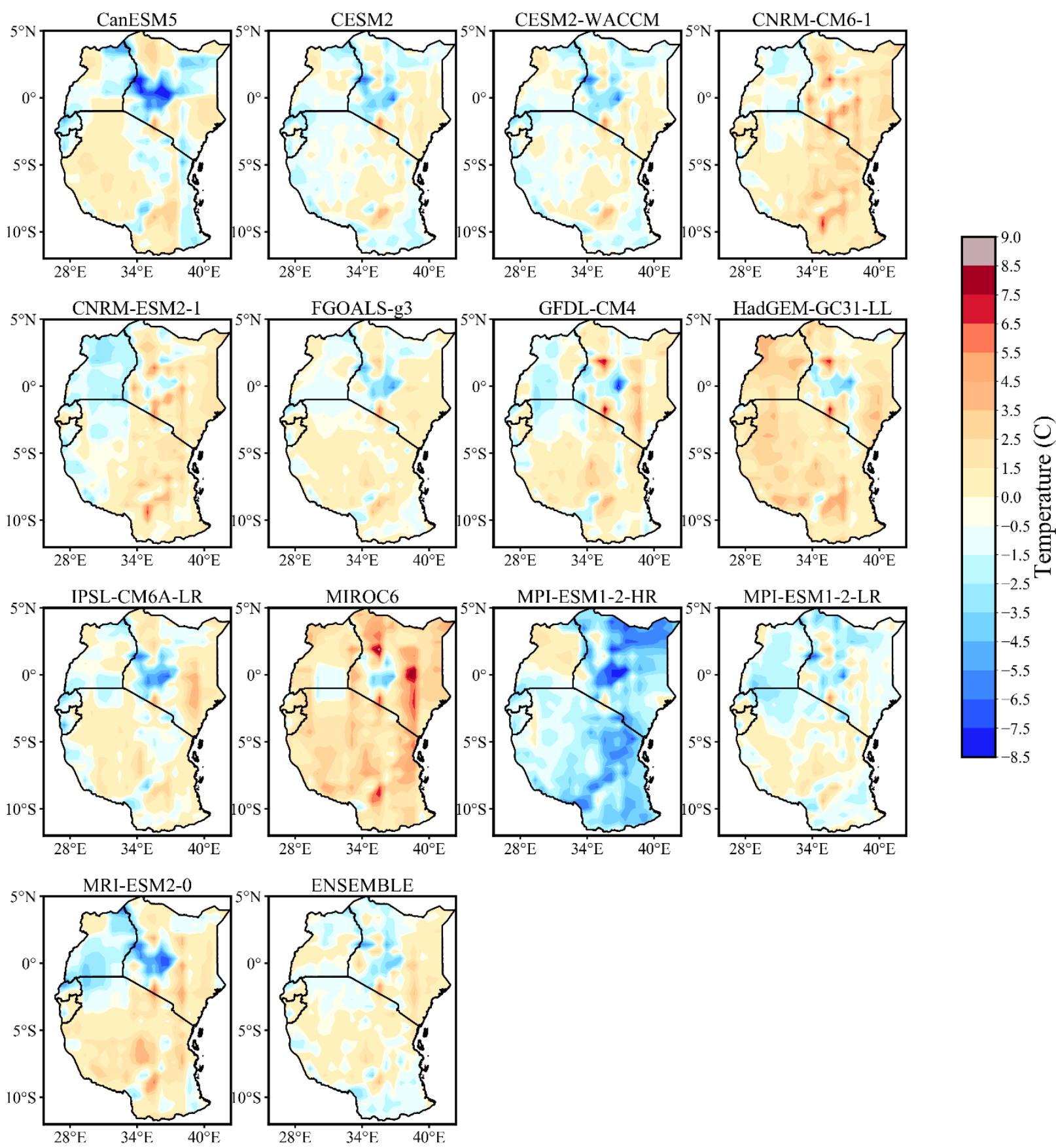

Figure 3. Spatial distribution of mean annual temperature bias (models minus observed) of the thirteen CMIP6 models and the mean ensemble over EA region during 1970 - 2014.

The models' ability to reproduce the linear spatial trends varies from one model to another, as presented in Figure 4 and Table 2, respectively. Most of the models simulated the trends within the observed ' 'range's proximity except CESM2 and CNRM-ESM2-1, which depict a higher positive annual temperature trend. Furthermore, as shown in Figure 4, a positive spatial linear trend of 0 to $0.02{ }^{\circ} \mathrm{C} /$ year is observed over most parts of the region during the period $1970-2014$. In 
total, 7/13 models depict an agreeable trend for similar to the observed pattern. These include FGOALS-g3, GFDL-CM4, HadGEM-GC31-LL, CESM2-WACCM, IPSL-CM6A-LR, MRIESM2-0 and MPI-ESM1-2-HR. However, the models MIROC6, CNRM-ESM2-1, and CESM2 showed the highest positive linear trend for annual temperature. Overall, the models well reproduce the spatial trends of T2m during the study period over the study domain. Most models recorded higher spatial trends over the western sides of the study area around Uganda, Rwanda, Burundi, and parts of Tanzania. These results are attributed to the increase in incoming thermal radiation in the region due to the reduction in vegetation cover extending from Congo Forest and surface heat loss (Nogheretto et al., 2013; Malhi et al., 2013; Bell et al., 2015). Other factors attributed to the increased trends in $\mathrm{T} 2 \mathrm{~m}$ could be associated to surface-based feedbacks, increase in thermal radiation budget, aerosols concentrations, increasing urbanization rates, increasing industrial population growth, and intensive land-use change practices (IPCC, 2014).

The trends were further evaluated and tested for their significance and magnitude. Table 2 shows the mean, slope, Z-score, and significance of linear trend of T2m for CRU and the 13 CMIP6 models. The observed T2m over the region exhibits significant increasing trends during the study duration. The observed mean (Z-score) values are $23.3^{\circ} \mathrm{C}$ (5.93) during $1970-2014$. These results agree with past studies over the study area (Camberlin, 2017; Ongoma et al., 2017; Camberlin, 2018). Remarkably, all models agree on the linear trajectory of T2m over the study region, with CMIP6 models depicting statistically increasing trends. Some models showed higher (lower) mean (Z-score) values, whereas others depicted a closer range. The MIROC6 showed a higher mean value of $25.7^{\circ} \mathrm{C}$ while IPSL-CM6A-LR demonstrated contrary values of $21.9^{\circ} \mathrm{C}$. The model ensemble exhibited slightly higher magnitude of change with weaker linear trendsthan the observed values. Overall, the following models showed consistent performance over the study domain: MPI-ESM-2-LR, HadGEM-GC31-LL, FGOALS-g3, and CNRM-ESM2-1. 

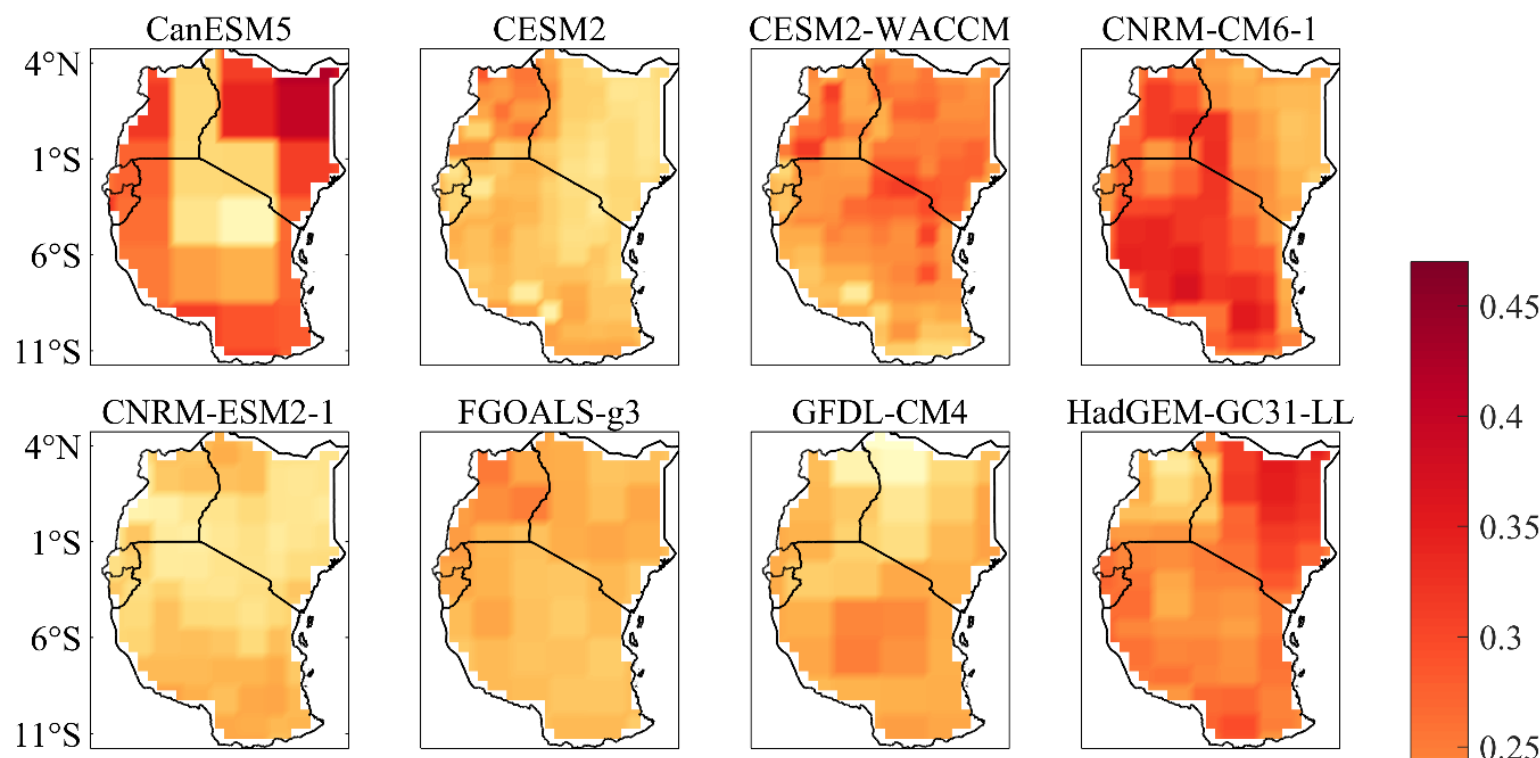

0.4
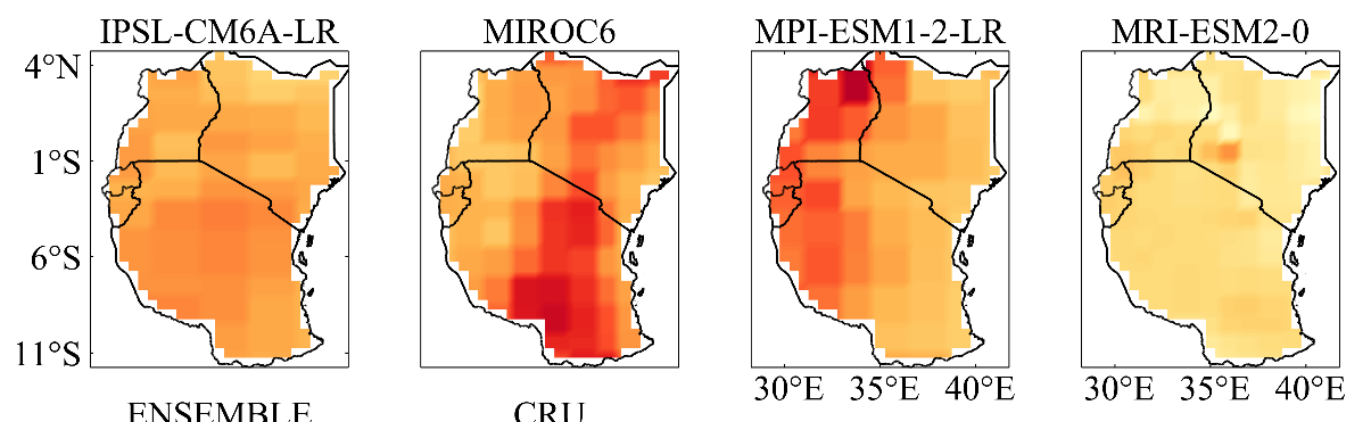

0.35
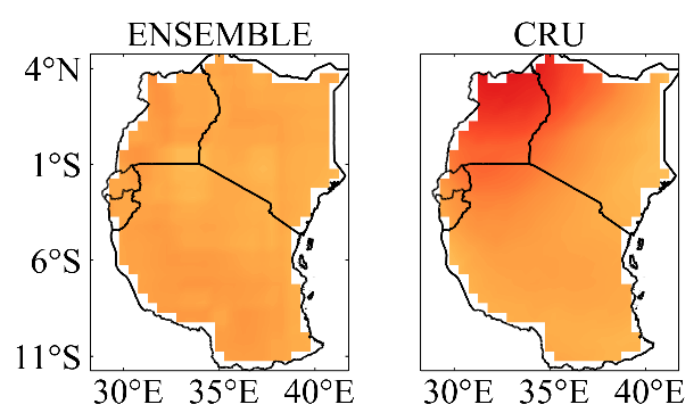

Figure 4. Spatial distribution of annual mean temperature trends $\left({ }^{\circ} \mathrm{C}\right.$ per decade) for the CMIP6 models, the mean ensemble and observation over EA during $1971-2014$. 
Table 2. Linear trend and Mann-Kendall trends of annual mean temperature over EA region during 1970 - 2014 using the CRU and CMIP6 models datasets.

\begin{tabular}{|c|c|c|c|c|c|}
\hline \multirow[t]{2}{*}{ Model } & \multicolumn{3}{|c|}{ Annual temperature trends } & \multirow[b]{2}{*}{ MK-tend } & \multirow[b]{2}{*}{$\bar{\Delta} / \mathbf{\nabla}$} \\
\hline & Mean & Slope (으/year) & Z-score & & \\
\hline Observed & 23.30 & 0.021 & 5.93 & $<0.0001$ & $\Delta=$ \\
\hline CanESM5 & 23.87 & 0.024 & 4.90 & $<0.0001$ & $\Delta=$ \\
\hline CESM2 & 24.11 & 0.015 & 4.35 & $<0.0001$ & $\Delta=$ \\
\hline CESM2-WACCM & 24.10 & 0.0194 & 5.01 & $<0.0001$ & $\Delta=$ \\
\hline CNRM-CM6-1 & 22.85 & 0.023 & 5.39 & $<0.0001$ & $\Delta=$ \\
\hline CNRM-ESM2-1 & 23.64 & 0.012 & 3.92 & $<0.0001$ & $\Delta=$ \\
\hline FGOALS-g3 & 23.56 & 0.017 & 4.95 & $<0.0001$ & $\Delta=$ \\
\hline GFDL-CM4 & 22.05 & 0.016 & 4.39 & $<0.0001$ & $\Delta=$ \\
\hline HadGEM-GC31-LL & 23.71 & 0.024 & 6.13 & $<0.0001$ & $\Delta=$ \\
\hline IPSL-CM6A-LR & 21.85 & 0.019 & 4.49 & $<0.0001$ & $\Delta=$ \\
\hline MIROC6 & 25.66 & 0.025 & 4.35 & $<0.0001$ & $\Delta=$ \\
\hline MPI-ESM1-2-HR & 24.17 & 0.017 & 4.54 & $<0.0001$ & $\Delta=$ \\
\hline MPI-ESM1-2-LR & 23.34 & 0.022 & 4.33 & $<0.0001$ & $\Delta=$ \\
\hline MRI-ESM2-0 & 23.74 & 0.010 & 3.33 & $<0.0001$ & $\Delta=$ \\
\hline ENSEMBLE & 23.59 & 0.018 & 7.31 & $<0.0001$ & $\Delta=$ \\
\hline
\end{tabular}

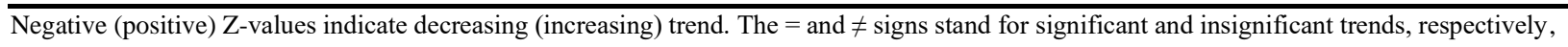
at $95 \%$ confidence interval.

Further analysis for the trend is conducted based on the model capability to simulate the observational time-series of T2m anomalies. Figure 5 shows T2m anomalies over EA region for individual CMIP6 GCMs, mean ensemble, and corresponding observed datasets during 1970 2014. Results for the model's ensemble are consistent with CRU trends, especially after 1990 with 
a positive trajectory noted. The warming tendencies observed in the ensemble mean are closer to the observed data, despite the higher amplitude depicted by observation during the period $2002-$ 2003. Notably, the model ensemble was unable to reproduce some of the major anomalous years (i.e., 1983, 1985, 1987, 1987, and 2003). This shows the inability of the models to capture the interannual variability of temperature trends. This feature has been noted in other regions, with models demonstrating incapability to capture major climatic anomalies (Sylla et al., 2013; Gbobaniyi et al., 2013; Ayugi et al., 2020a).

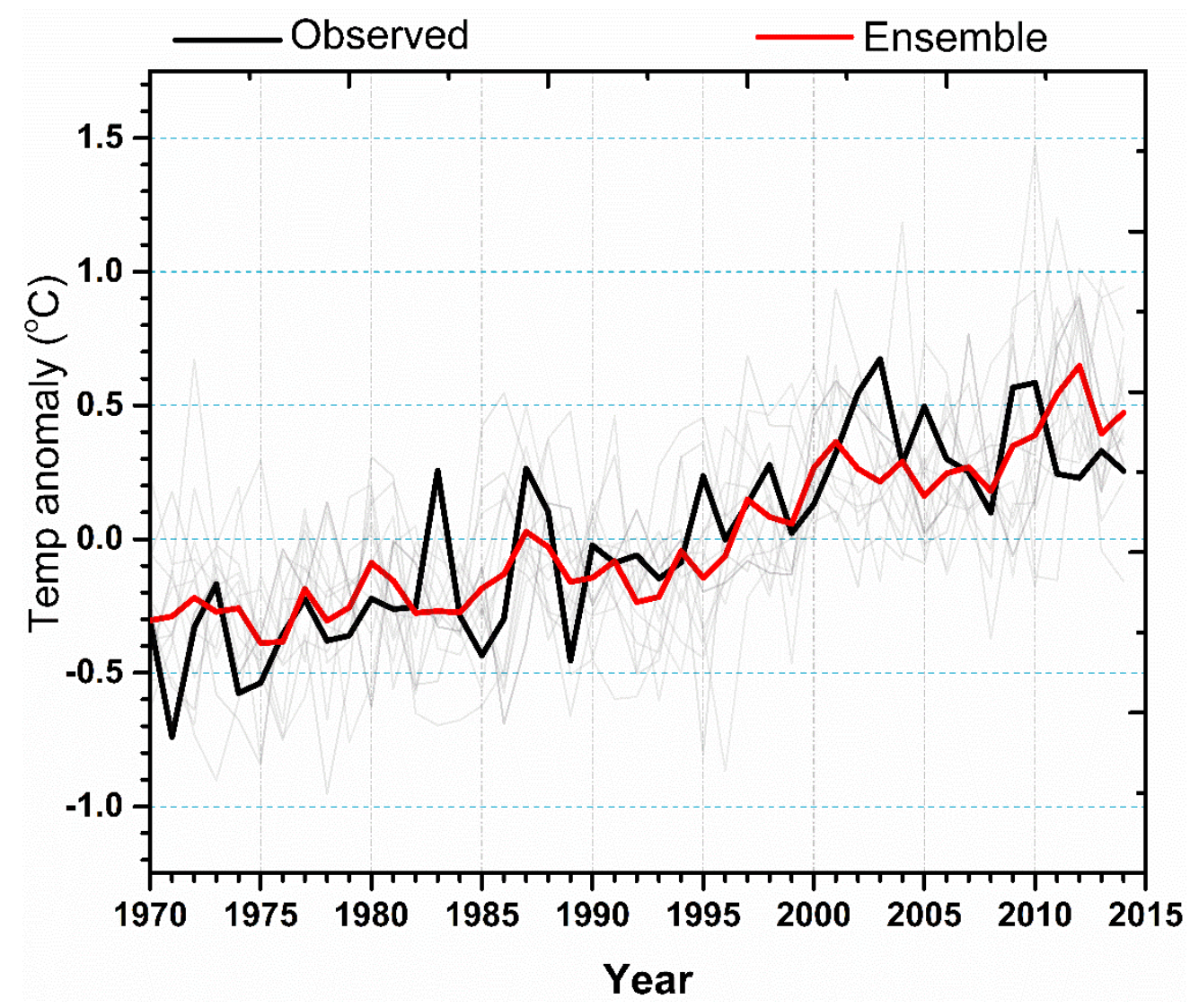

Figure 5. Time series of annual mean temperature anomalies over EA region for individual CMIP6 GCMs, mean ensemble and corresponding observed datasets. The gray lines show individual models, while the bold lines are the ensemble and observed data.

The summary of model performance relative to observation over the study region is presented in Figure 6. The majority of GCMs depicted a larger standard deviation than observation with only six models (i.e., HadGEM-GC31-LL, FGOALS-g3, MPI-ESM-2-LR, MRI-ESM2-0, CESM2, and CESM2-WACCM) reproducing similar or smaller standard deviation. Conversely, most CMIP6 models (i.e., 7/13) simulated higher amplitudes depicting a large spatial variation of warming. The mean ensemble demonstrates better performance relative to observation, while 
MIROC6 shows the largest warm bias associated with overestimations. Spatial correlation analysis of the models highlights acceptable simulations by most CMIP6 models, with MIROC6 depicting the worst performance (CC; 0.29). The CMIP6 models ensemble shows robust simulations compared with individual models with > 0.90. Generally, temperature GCMs demonstrate good performance in reproducing observed spatial patterns over EA domain in the new model generation due to the improved parametrization schemes, enhanced spatial resolution, and physical processes, including the biogeochemical cycles (Eyring et al., 2016). Comparative studies across other domains equally show varying performances, with some studies depicting a slight improved performance of CMIP6 relative to CMIP5 in simulating climate variables (Xin et al., 2020; Zhu et al., 2020; Zamani et al., 2020; Zhu and Saini, 2020).

The best performing models for this analysis are: CESM2, CESM2-WACCM, HadGEMGC31-LL, FGOALS-g3, and MPI-ESM2-LR. The consistently poor performance in MIROC6 is noteworthy with attributions to the unskillful simulation of regional climate due to the model's ocean biogeochemical component that has been primarily updated to simulate the biogeochemical cycles of carbon, nitrogen, phosphorous, iron, and oxygen (Hamija et al., 2020). Duan et al. (2013) suggested that the indirect effect of sulfate aerosol could enhance the 'model's capability to simulate the annual and seasonal climate patterns. Conversely, the mentioned chemical (sulfate) was primarily missed in the recent updated biogeochemical cycle in the MIROC6 model. This shows that the enhancement of the mechanism for the observed bias remains a challenge. 


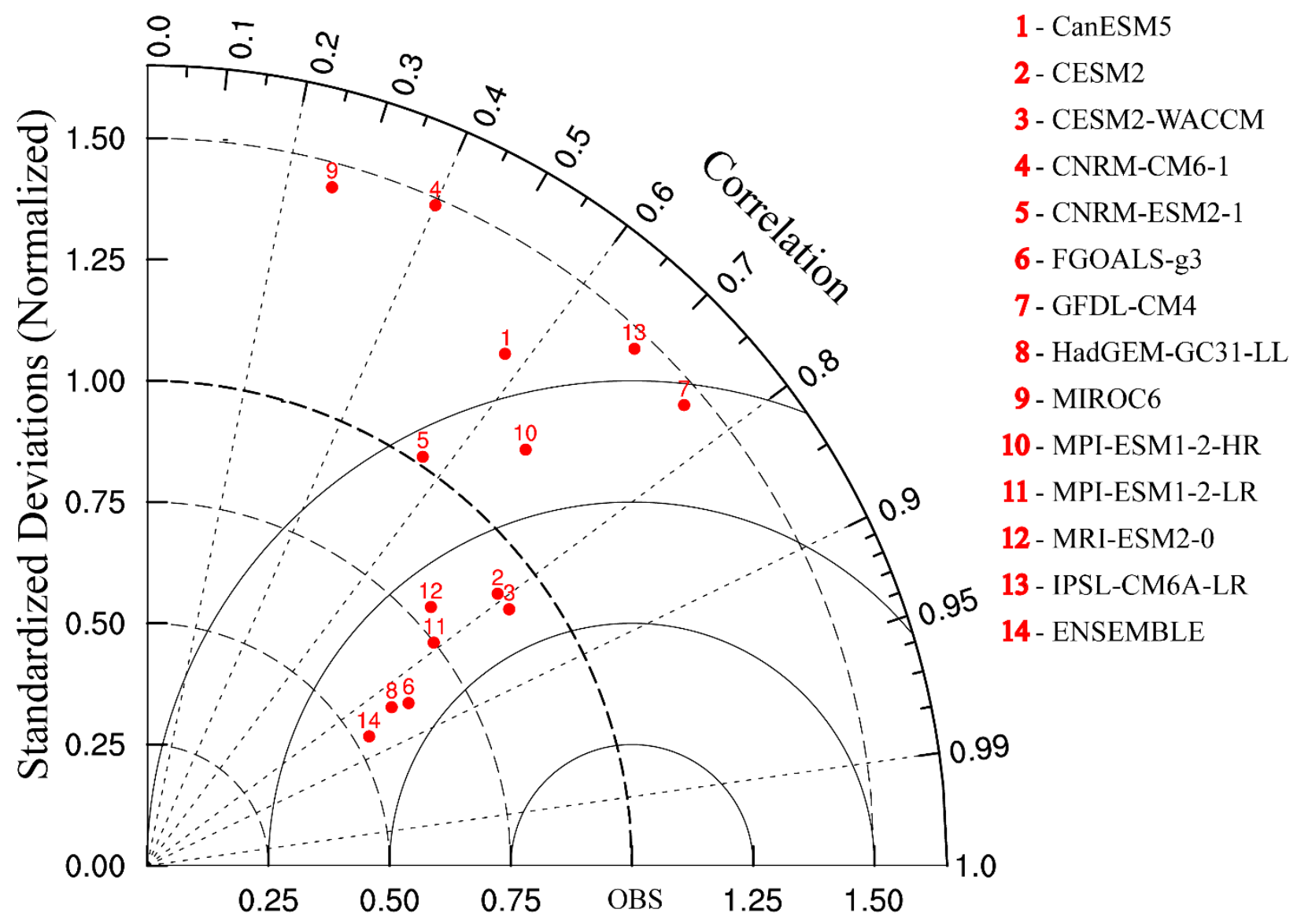

Figure 6. Taylor diagram for the climatological annual temperature over EA region land surface of the CMIP6 models and observation for 1970 - 2014. The radial coordinate is the magnitude of the standard deviation (denoted by the arcs). The root mean square difference is shown using the concentric semi-cycle. The angular coordinate depicts the correlation coefficient.

Finally, model overall ranking is established using the Taylor skill score (TSS) metrics. Figure 7 presents the TSS for the thirteen T2m models and their mean ensemble over East Africa. Principally, the TSS values closer to 1 depict better performance. The values of the TSS for all the models are listed in Table 3. The model ensemble for T2m shows higher values as compared to individual models. The worst performance is reflected in the simulation of MRI-ESM2-0 with TSS of 0.44 , while the ensemble has TSS of 0.76 . The model variability score for other TSS ranges from 0.5 to 0.70 . The overall ranking of the models from all the analyses ranging from mean cycle simulation, trend analysis, interannual variability, spatial patterns variability based on RMSE, bias, and CC are as follows: FGOALS-g3, HadGEM-GC31-LL, MPI-ESM1-2-LR, CNRM-CM6-1, and IPSL-CM6A-LR. The best performing models will thus be used to build an ensemble for future projection of the possible climate change scenario over the region. 


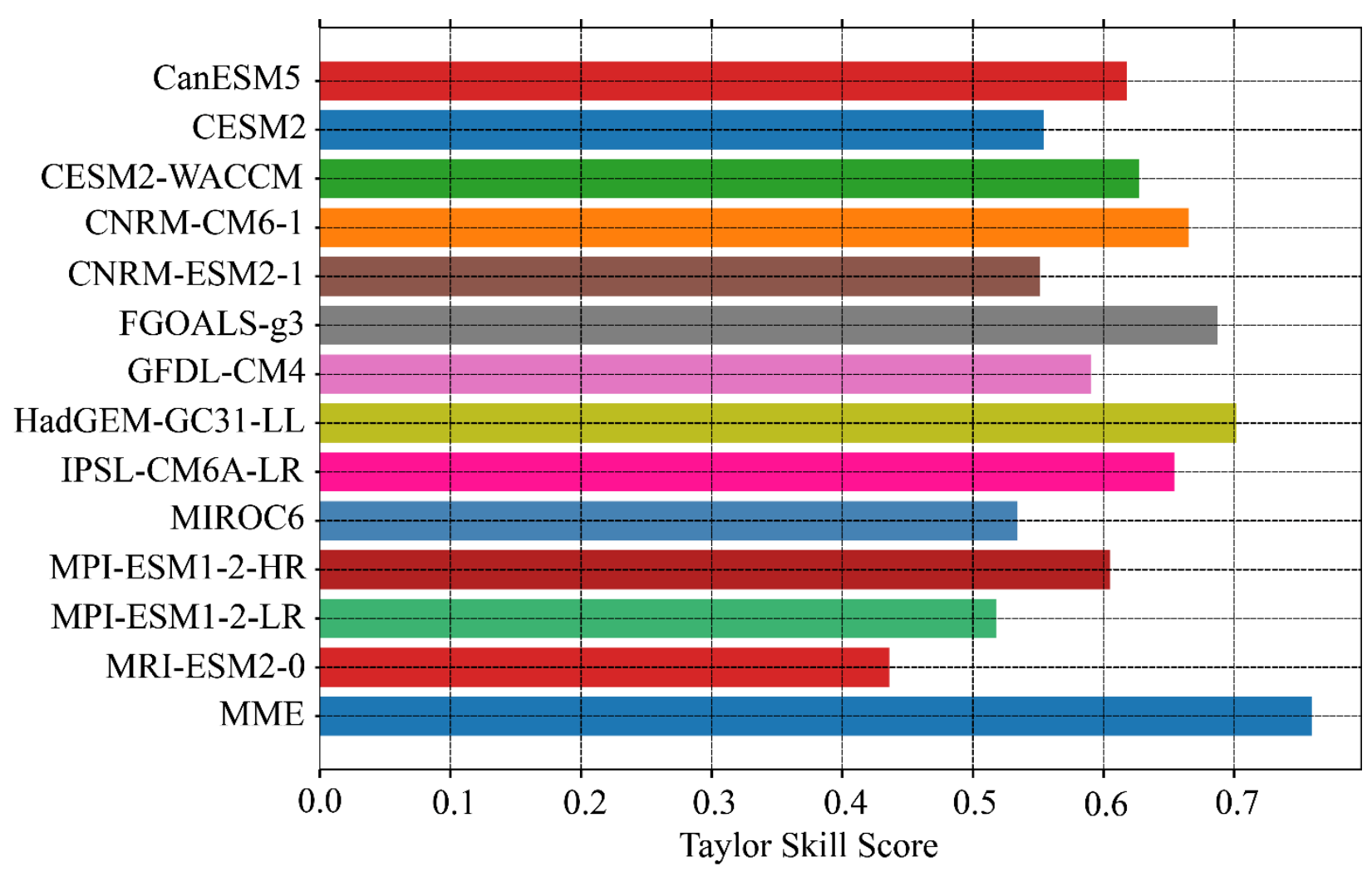

Figure 7. Taylor skill score (TSS) and ranking for mean temperature over EA. The TSS closer to 1 denotes better model performance. 
Table 3. Statistical metrics of CMIP6 model represented model's Taylor skill score (TSS), correlation coefficient (CC), root mean square error (RMSE), and bias over EA during 1970 2014.

\begin{tabular}{|l|l|l|l|l|}
\hline Model & CC & RMSE & Bias & TSS \\
\hline CanESM5 & 0.65 & 0.68 & -0.57 & 0.62 \\
\hline CESM2 & 0.49 & 0.87 & -0.81 & 0.55 \\
\hline CESM2-WACCM & 0.58 & 0.87 & -0.80 & 0.63 \\
\hline CNRM-CM6-1 & 0.67 & 0.56 & 0.45 & 0.67 \\
\hline CNRM-ESM2-1 & 0.48 & 0.47 & -0.34 & 0.55 \\
\hline FGOALS-g3 & 0.68 & 0.377 & -0.25 & 0.68 \\
\hline GFDL-CM4 & 0.54 & 1.29 & 1.25 & 0.60 \\
\hline HadGEM-GC31-LL & 0.69 & 0.50 & -0.41 & 0.70 \\
\hline IPSL-CM6A-LR & 0.63 & 1.48 & 1.45 & 0.65 \\
\hline MIROC6 & 0.55 & 2.39 & -2.36 & 0.53 \\
\hline MPI-ESM1-2-HR & 0.55 & 0.93 & -0.87 & 0.61 \\
\hline MPI-ESM1-2-LR & 0.47 & 0.40 & -0.04 & 0.52 \\
\hline MRI-ESM2-0 & 0.37 & 0.55 & -0.44 & 0.44 \\
\hline ENSEMBLE & 0.78 & 0.35 & -0.28 & 0.76 \\
\hline
\end{tabular}

\subsection{Temperature projections for the $21^{\text {st }}$ century}

Examination of possible changes in T2m over EA is conducted using two main scenarios representing plausible trajectories: modest mitigation scenarios (i.e., SSP2-4.5) or worst-case no policy possible pathways (and SSP5-8.5) (Riahi et al., 2017). Figure 8 shows the annual projected changes in T2m for the 2015 - 2100 timeline based on the best performing models and their respective MME under two scenarios. The projected changes over the study domain exhibit warming tendency with highest (lowest) values under SSP2-4.5 projected at $1.8^{\circ} \mathrm{C}\left(1.2^{\circ} \mathrm{C}\right)$ and at $3.2{ }^{\circ} \mathrm{C}\left(1.5^{\circ} \mathrm{C}\right)$ under the SSP5-8.5 scenario. The MME projects $1.6^{\circ} \mathrm{C}\left(2.4^{\circ} \mathrm{C}\right)$ warming over the study region for the SSP2-4.5 (5-8.5) scenario (Figure 8a, b). During the three time slices under consideration, the MME projects many changes during the late period $(2080-2100)$ with expected mean changes at $2.4{ }^{\circ} \mathrm{C}$ for SSP2-4.5 and $4.4{ }^{\circ} \mathrm{C}$ for the SSP5-8.5 scenario. On the 
contrary, the near future $(2020-2049)$ is expected to experience $1.0^{\circ} \mathrm{C}$ warming under the modest mitigation pathways, whereas $1.1^{\circ} \mathrm{C}$ mean changes in $\mathrm{T} 2 \mathrm{~m}$ are expected if no mitigation measures to curb the GHG emissions are put into place. The findings of this study agree with previous studies conducted over varying regions in Africa using CMIP5 models (Ongoma et al., 2018b; Libanda and Ngonga, 2018). The study noted a projected increase in $\mathrm{T} 2 \mathrm{~m}$ by about $2.4{ }^{\circ} \mathrm{C}$ and $4.1{ }^{\circ} \mathrm{C}$ under the RCP4.5 and RCP8.5 scenarios. Further, the result of the present study is in harmony with a recent survey conducted over the entire Africa with a focus on various sub-regions such as Central East Africa (CEAF) and southeast Africa (SEAF) (Almazroui et al., 2020a). To illustrate, the study demonstrated a $66 \%$ range of projected warming over CEAF and SEAF during the last period of the century with expected warming at $2.7^{\circ} \mathrm{C}-4.9^{\circ} \mathrm{C}$ under the SSP5-8.5 scenario.

It is interesting to note that while the region is expected to warm rapidly, projections on precipitation show an increase in rainfall over the study domain (Shongwe et al., 2011; Ongoma et al., 2018; Osima et al., 2018; Ayugi et al., 2021). The expected recovery in precipitation is likely to offset the impacts of warming, which could adversely impact agriculture due to the sharp increase in evapotranspiration and subsequent increase in drought and aridity. The historical patterns over the EA region have been characterized by many occurrences of drought/flood incidences, which are mainly a result of anthropogenic influence and changes associated with internal variability; e.g., by El Nino Southern Oscillation(ENSO) and Interdecadal Pacific Oscillation (IPO) (Gu et al., 2013; Lyon, 2014; Hua et al., 2016; Dai, 2016). Overall, the best performing CMIP6 models show the capability to reasonably project possible future temperature changes over the study region (Figure 8a, b). Higher warming is expected during the last century under the SSP5-8.5 scenario. The temperature changes are likely to impact various sectors such as health, energy, agriculture and societal infrastructure during the mid and late century. This will call for robust policy changes to be instituted to avoid loss of livelihoods and property. 


\subsection{Temperature projections for the $21^{\text {st }}$ century.}

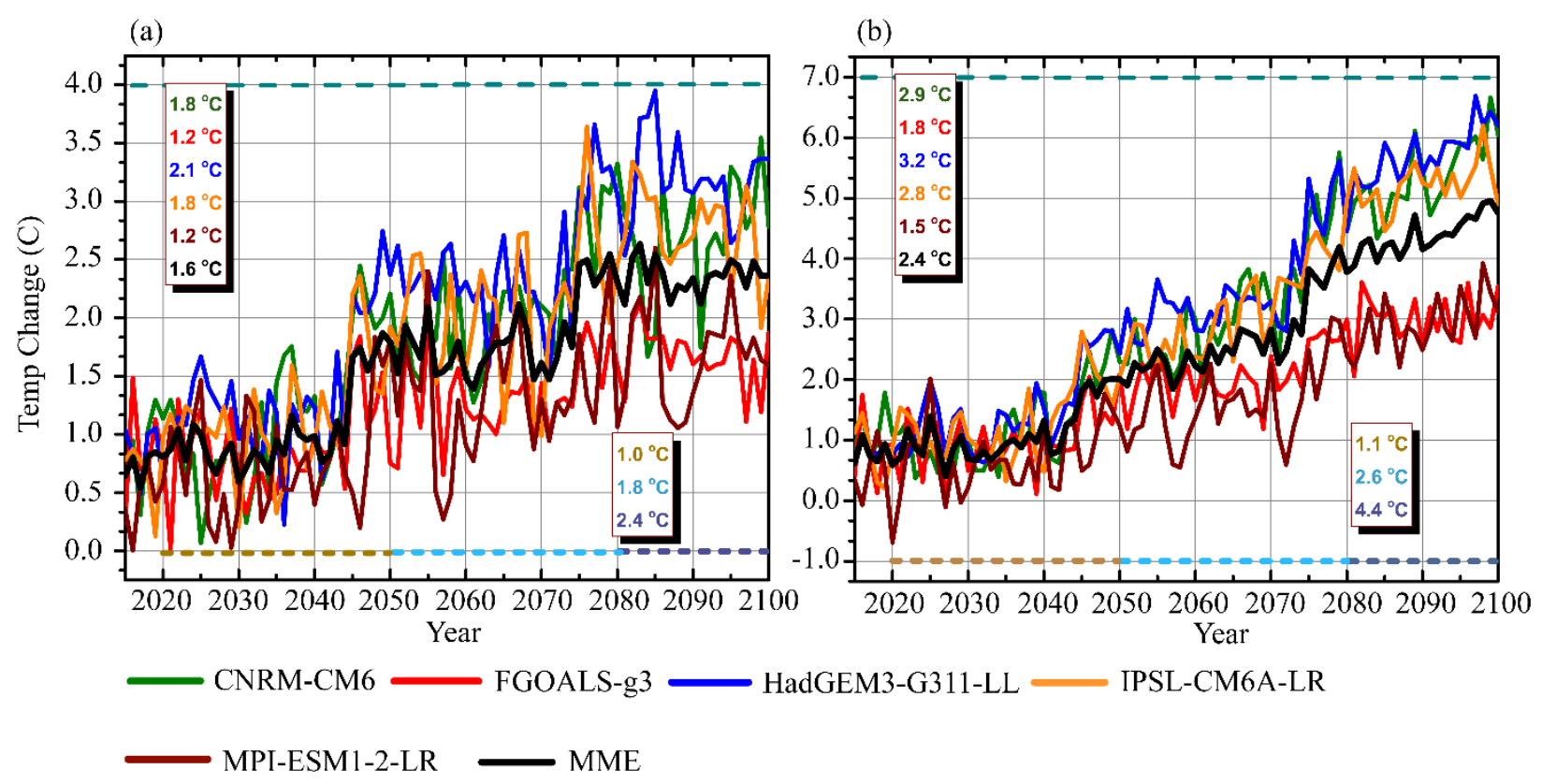

Figure 8. Annual projected changes in surface mean temperature $\left({ }^{\circ} \mathrm{C}\right)$ over the EA region defined for the 2015-2100 timeline based on best performing models and their respective multi-model ensemble mean (MME) under (a) SSP2 - 4.5, and (b) SSP5 - 8.5 scenarios. The dashed color linked boxes represent the mean changes projected for the near-term (2020 2049), mid-term (2050 - 2079), and long-term (2080 - 2100), respectively. The upper dashed line box show projections for 2015-2100 timescale.

The spatial distribution of projected changes in T2m over EA is described in Figure 9. The analysis shows warming under varying time scale, relative to the baseline period. The significance of the changes is further tested based on linear trends and m-MK analysis (Figure 10 and Table 4). Notably, the projections based on the SSP2-4.5 scenario during the near future show minimal warming with net change not exceeding $0{ }^{\circ} \mathrm{C}$ from the current temperature experienced (Figure 9a). However, towards the end of the century, pronounced patches of warming of $0.8{ }^{\circ} \mathrm{C}-1.4{ }^{\circ} \mathrm{C}$ are expected over eastern parts of Kenya and western Kenya along with Lake Victoria (Figure 9c). Under the SSP5-8.5 scenario, significant homogeneous warming is expected over the whole region exceeding $7{ }^{\circ} \mathrm{C}$ warming from current levels with more pronounced change over Tanzania and Uganda (Figure 9f). 
The magnitude of change based on Sen's slope estimator and m-MK reveal significant increasing tendencies with projections of $0.24{ }^{\circ} \mathrm{C}$ decade $^{-1}\left(0.65{ }^{\circ} \mathrm{C}\right.$ decade $\left.^{-1}\right)$ under SSP2-4.5 (SSP5-8.5) scenarios, respectively (Figure 10 and Table 4). A previous study over a similar domain based on CMIP5 depicted a likely increase at $0.2^{\circ} \mathrm{C}$ decade $^{-1}$ and $0.5{ }^{\circ} \mathrm{C}$ decade $^{-1}$ under RCP4.5 and RCP8.5 (Ongoma et al., 2018b). The result of the present study shows a higher warming tendency relative to the outputs of CMIP5 models. In agreement with other studies, Almazroui et al. (2020a) reported $0.22^{\circ} \mathrm{C}\left(0.49^{\circ} \mathrm{C}\right)$ for SSP2-4.5 (SSP5-8.5) over CEAF and relatively similar values over SEAF domains, representing the Greater Horn of Africa (GHA). Comparative analysis of warming trends shows larger warming over Asia and North America than global land surface area (Fan et al., 2020). For instance, warming trends over North America and Asia, and Europe are $\sim 7^{\circ} \mathrm{C}-8.5^{\circ} \mathrm{C} / 100 \mathrm{yr}$, while those in Africa, South America and Australia exceed $6{ }^{\circ} \mathrm{C} / 100$ yr (Fan et al., 2020). A higher rate of warming is likely to result in extreme events over most parts of the globe (Huang et al., 2017; Lehner et al., 2017; Dosio et al., 2018; Kharin et al., 2018). Recent studies have reported intensified extreme events over the African continent in the wake of persistent global warming (Ongoma et al., 2017; Osima et al., 2018; Gebrechorkos et al., 2018). To illustrate, Iyakaremye et al. (2020) revealed considerable warming in Sahara and South Africa, with the highest changes expected in daily maximum temperature $(\mathrm{TXx})$ at $1.6^{\circ} \mathrm{C} / 2.5^{\circ} \mathrm{C}$ under Paris accord targets of $1.5{ }^{\circ} \mathrm{C}$ and $2.0^{\circ} \mathrm{C}$ relative to the pre-industrial levels. The study further showed an anticipated decline in the frequency of cold days (TN10p) in large portions of the African continent, except for the west Africa region. Such changes call for urgent action from all relevant stakeholders to devise appropriate policies to reflect the regional and global climate changes for sustainable living. 
(a) 2020-2049 SSP 245

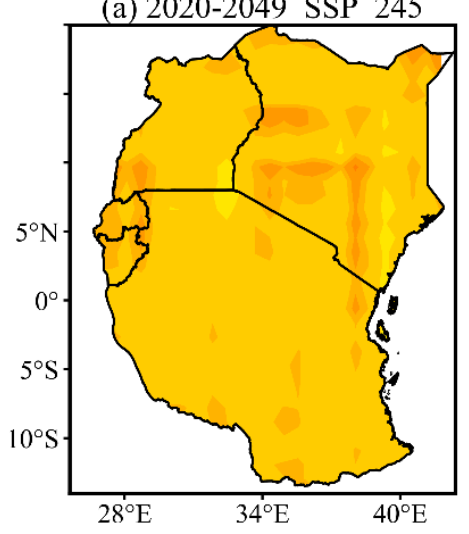

(d) 2020-2049 SSP 585

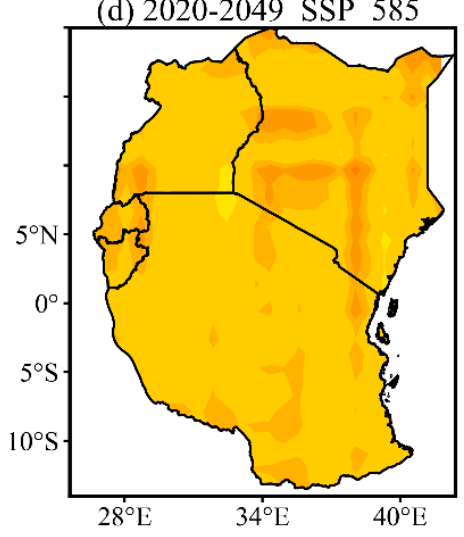

(b) 2050-2079 SSP 245

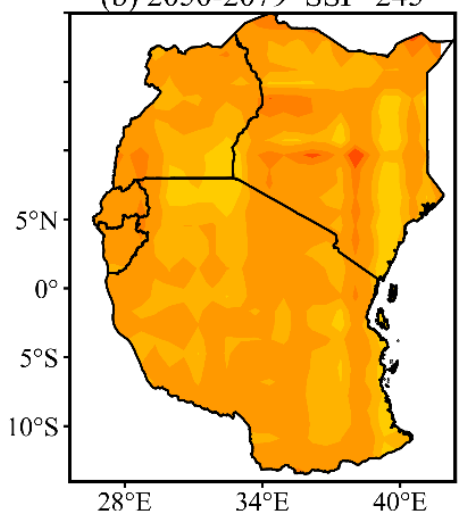

(e) 2050-2079 SSP 585

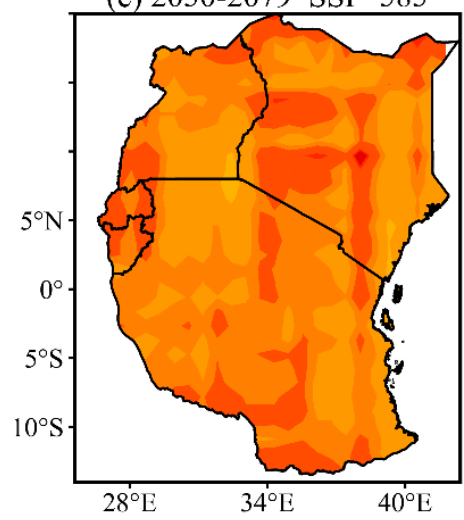

(c) 2080-2099 SSP 245
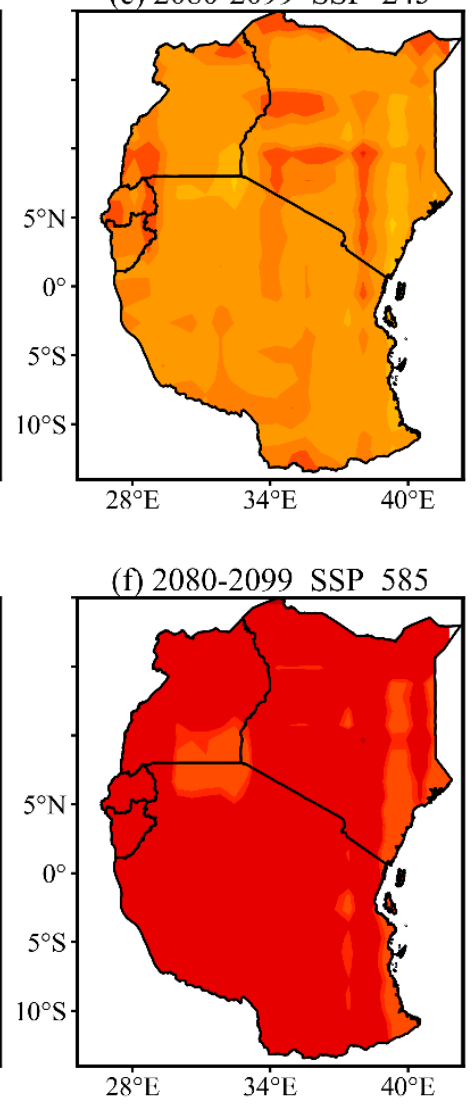

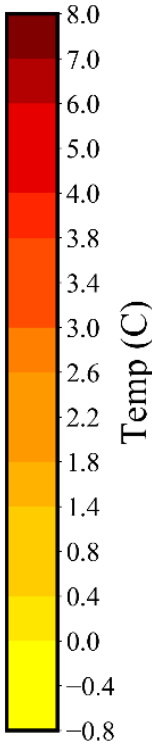

Figure 9. Spatial distribution of changes in annual mean temperature over EA region in nearterm (2020 - 2049), mid-term (2050 - 2079), and long-term $(2080-2100)$ periods of the $21^{\text {st }}$ century, relative to $1985-2014$, under the SSP2 -4.5 and SSP5 -8.5 scenarios. 
(a) 2020-2049 MME 245

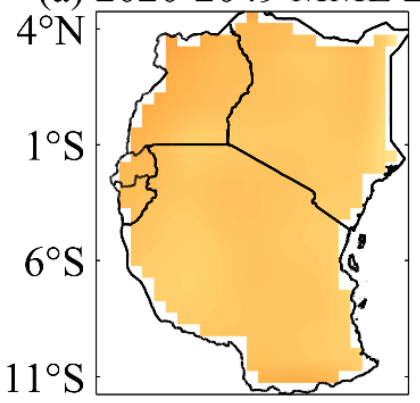

(d) 2020-2049 MME 585

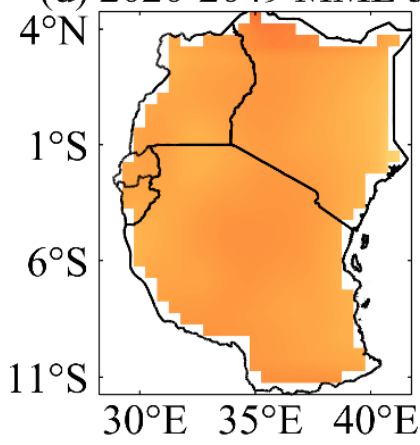

(b)

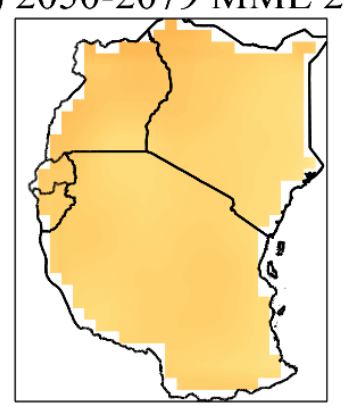

(e) 2050-2079 MME 585

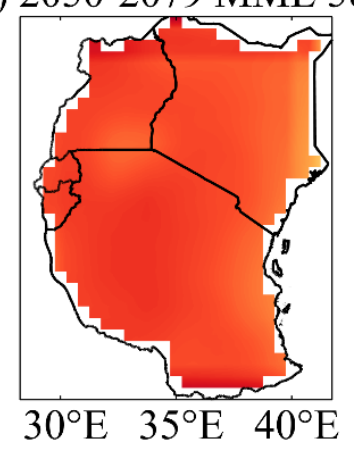

(c) 2080-2098 MME 245
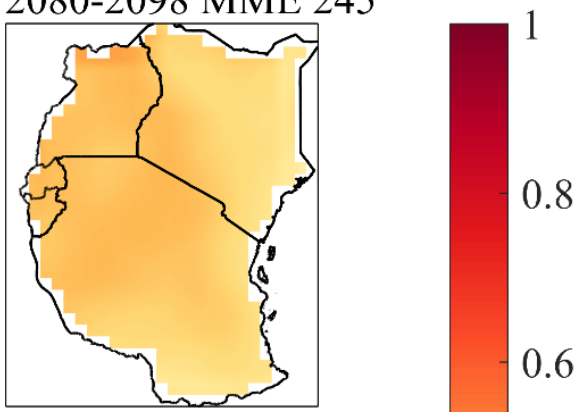

(f) 2080-2098 MME 585

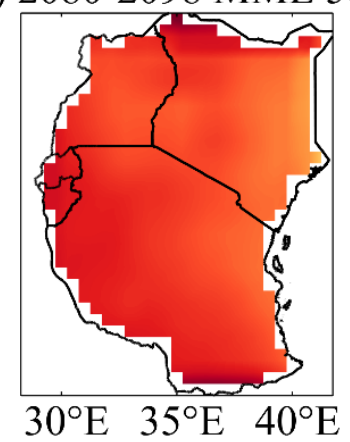

0.8

0.6

0.4

$-0.2$

0

Figure 10. Spatial distribution of annual mean temperature trends $\left({ }^{\circ} \mathrm{C}\right.$ per decade) over EA land surface in near-term (2020 - 2049), mid-term (2050 - 2079), and long-term (2080 - 2100) periods of the $21^{\text {st }}$ century under the SSP2 -4.5 and SSP5 -8.5 scenarios.

Table 4. Linear trend and Mann-Kendall trends of annual mean temperature over EA region in near-term (2020 - 2049), mid-term (2050 - 2079), and long-term (2080 - 2100) periods under the SSP2 - 4.5 and SSP5 - 8.5 scenarios based on MME of CMIP6 models. * indicates significant trend at $5 \%$ significance level.

\begin{tabular}{|c|c|c|c|c|}
\hline \multirow[t]{2}{*}{ Scenario } & Period & $\bar{x}=\sum_{n} x$ & $\Delta 10^{-1}$ & $\Delta / \nabla$ \\
\hline & Near-te & & & \\
\hline SSP245 & & 24.34 & 0.33 & $\mathbf{\Delta}^{*}$ \\
\hline \multirow[t]{2}{*}{ SSP585 } & & 24.40 & 0.41 & $\mathbf{\Delta}^{*}$ \\
\hline & Mid-ter & & & \\
\hline SSP245 & & 25.16 & 0.26 & $\mathbf{\Delta}^{*}$ \\
\hline \multirow[t]{2}{*}{ SSP585 } & & 25.96 & 0.62 & $\mathbf{\Delta}^{*}$ \\
\hline & Long-te & & & \\
\hline SSP245 & & 25.67 & 0.24 & $\mathbf{\Delta}^{*}$ \\
\hline SSP585 & & 27.68 & 0.65 & $\mathbf{\Delta}^{*}$ \\
\hline
\end{tabular}


Finally, the changes in the variability and skewness of T2m over the EA region are presented using the PDFs (Figure 11). Figures 11a and 11b display the predictable PDFs from CMIP6 mean under different scenarios, with a baseline period of 1985 - 2014 and projected timescales subdivided into three periods, namely, near-term (2020 - 2049), mid-term (2050 2079), and long-term (2080 - 2100). Relative to baseline curves, the SSP5-8.5 scenario shows a clear pattern of a condensed peak, increased spread and a mean shift to the right, inferring large increases in the frequencies of warm extremes over the study region. The changes during SSP24.5 depict stabilization patterns towards the end of the century with the high peaks, higher than that of the observed period, and a noticeable increase in mean values of $\mathrm{T} 2 \mathrm{~m}$ at $25{ }^{\circ} \mathrm{C}-26^{\circ} \mathrm{C}$ (Figure 11a). Comparative analysis for SSP2-4.5 and SSP5-8.5 shows an increase in mean values from one time slice to another (Table 4). The results show more robust global warming changes than previous studies based on CMIP5 (Ongoma et al., 2018b). For instance, the PDFs for projected change during the $2071-2100$ period relative to the baseline period $(1961-1990)$ over EA shows that the mean temperature will be 25.2 and 26.7 under RCP4.5 and RCP8.5 scenarios, while the present study demonstrates that the projected change during the same period will be 25.6 and 27.7 under SSP2-4.5 and SSP5-8.5 scenarios, respectively (Figure 11 and Table 4). The results of the present study are in harmony with projected changes in T2m using CMIP6 over most regions (Grose et al., 2020; Fan et al., 2020; Tokarska et al., 2020; Almazroui et al., 2020a, b, c; Karim et al., 2021). The findings from this study illustrate higher warming in the latest model outputs of CMIP6 relative to its predecessor, despite identical instantaneous radiative forcing (Wyser et al., 2020). 

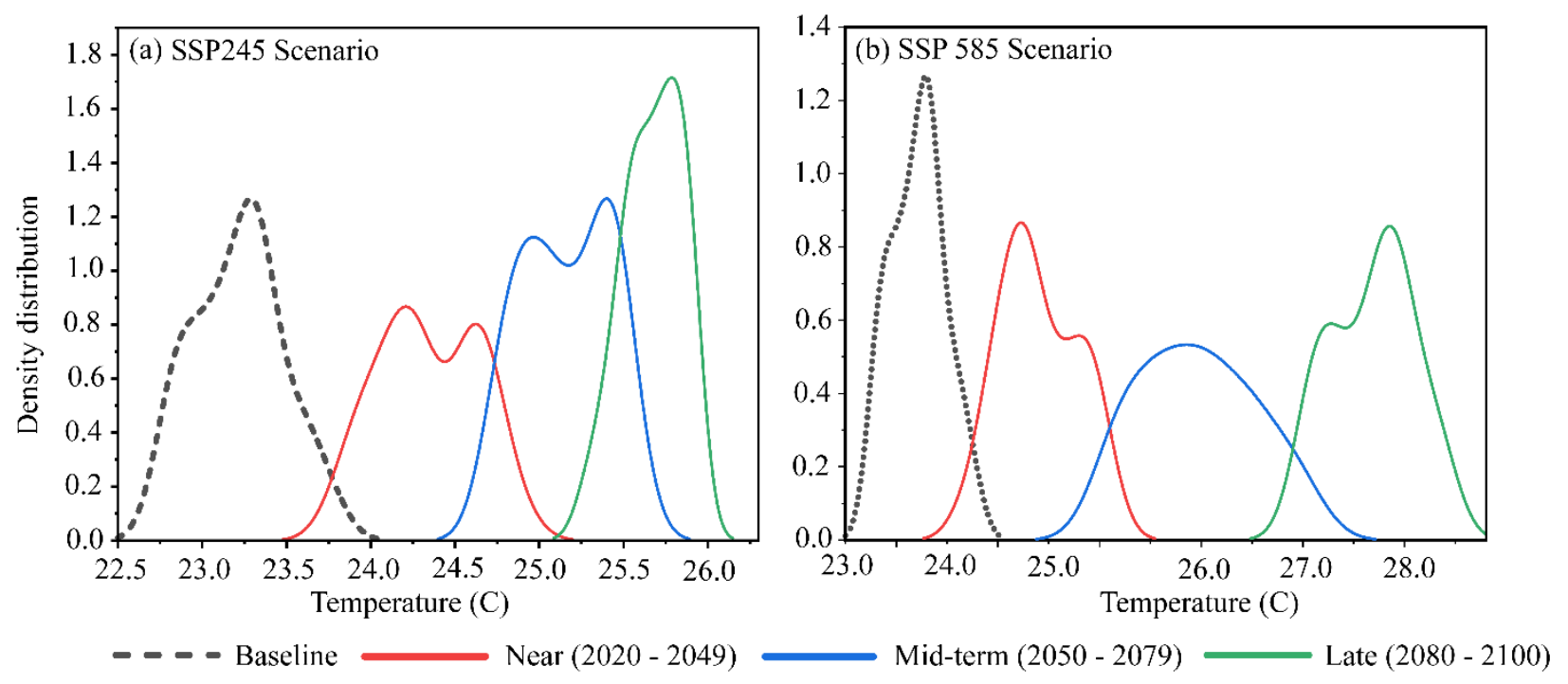

Figure 11. Probability density distribution of the annual mean temperature $\left({ }^{\circ} \mathrm{C}\right)$ over EA region in near-term $\left(2020\right.$ - 2049), mid-term $(2050-2079)$, and long-term $(2080-2100)$ periods of the $21^{\text {st }}$ century, relative to 1985 - 2014, under (a) SSP2 - 4.5, and (b) SSP5 - 8.5 scenarios

The impacts of anthropogenic activities on $\mathrm{T} 2 \mathrm{~m}$ are essential in understanding the present and future climate change, environment, and sustainable development (Siddique et al., 2020). Over EA region, rapid growth in transportation, industrialization, urbanization, deforestation, waste, agriculture, livestock, and energy use are the main drivers of GHG emissions and will result in countrywide temperature rise (Odada et al., 2020). By 2050, GHG emissions contribution by the energy and agriculture sectors may rise steadily while for manufacturing industry, land use/land use change-forestry, and waste management sector will equally face a varying shift in usage and quantity, respectively (UNEP, 2018). East Africa's population may grow up to 740 million by 2050, particularly in rural areas and around small cities (UNFPA, 2010). Due to promising economic opportunities, a large section of the population is bound to migrate to major commercial and industrial hubs (UNEP, 2018).

Conclusively, future population pressure, fossil fuel-based industrialization, transportation, commercialization, and land-use changes may intensify the GHG emissions and temperature rise over the EA region. It is necessary to study the evolution and variability in drivers of GHG emission and temperature increase over the study domain to understand future temperature warming-induced impacts in EA. Moreover, it will also help to develop comprehensive, national, and regional environmental, economic, disaster management, and climate change adaptation and mitigation policies. 


\section{Summary and Conclusion}

This study uses CMIP6 experiments to present an analysis of the ability of the models to simulate current T2m over East Africa and their future changes under three time slices, namely near-term (2020 - 2049), mid-term (2050 - 2079), and long-term (2080 -2100) periods of the $21^{\text {st }}$ century, relative to the historical period of 1985 - 2014. We examine future changes under modest mitigation and high-emission pathways (i.e., SSP2-4.5 and SSP5-8.5). The performance of models and MME in simulating annual T2m against the benchmark CRU is assessed using mean state, trends, bias, CC, RMSE, and Taylor skill score. The main findings are summarized as follows:

The CMIP6-simulated T2m indicate that most of the models can reproduce the climatological temperature patterns of the study region with an aspect of overestimation by the majority of model outputs. Only few models portrayed an underestimation of the annual cycle of $\mathrm{T} 2 \mathrm{~m}$. The spatial analysis demonstrates an underestimation in regions with a complex topography and over most areas of Uganda. Remarkably, CanESM5 shows an underestimation by more than $-6.5^{\circ} \mathrm{C}$ over the Mount Kenya region.

The ability of the models to reproduce the linear spatial trends varies from one model to another. Most of the models simulated the trends within the observed ' 'range's proximity except CESM2 and CNRM-ESM2-1, which depict a higher positive annual temperature trend. The majority of models recorded higher spatial trends over the western sides of the study area around Uganda, Rwanda, Burundi, and parts of Tanzania. The "models' overall ranking from all the analyses ranging from mean cycle simulation, trend analysis, interannual variability, spatial patterns variability based on RMSE, bias, and CC are as follows: FGOALS-g3, HadGEM-GC31LL, MPI-ESM1-2-LR, CNRM-CM6-1, and IPSL-CM6A-LR.

The projected changes over the study domain exhibit warming tendency with MME derived from best performing models showing warming over the study region by $1.6{ }^{\circ} \mathrm{C}\left(2.4{ }^{\circ} \mathrm{C}\right)$ for the SSP2-4.5 (5-8.5) scenarios. During the three time slices under consideration, the MME project many changes during the late period $(2080-2100)$ with expected mean changes at $2.4{ }^{\circ} \mathrm{C}$ for SSP2-4.5 and $4.4{ }^{\circ} \mathrm{C}$ for the SSP5-8.5 scenario. The magnitude of change based on Sen's slope estimator and m-MK reveal significant increasing tendencies during the late century at $0.24{ }^{\circ} \mathrm{C}$ decade $^{-1}\left(0.65^{\circ} \mathrm{C}_{\text {decade }}{ }^{-1}\right)$ under the SSP2-4.5 (SSP5-8.5) scenarios.

This ' 'study's findings illustrate higher warming in the latest model outputs of CMIP6 relative to its predecessor, despite identical instantaneous radiative forcing. Despite the robust 
results, some limitations feature the present study. Future studies may examine the response to different global warming threshold with more "models' outputs added to limit any uncertainty in the climate projections. Moreover, subsequent studies could also focus on extreme climate factoring the population exposure and local vulnerability following a novel study by Chen and Sun (2019) and Chen et al. (2020).

Authors contributions: All authors made an equal contribution to the manuscript's development and consented to the submission for publication. The following are individual contributions: BA: conceptualization, formal writing, funding, original draft preparation. HB, VI, and KTCLKS: Data curation, methodology, visualization. HG: writing-review and editing, investigation. VO and KTCLKS: Validation, writing-review, and editing.

Funding: Financial and material support received from National Key Research and Development Program of China (Grant No. 2017YFA0603804 and 2018YFC1507704), National Science Foundation of China (No. 41805048) is vastly appreciated.

Compliance with ethical standards: Authors agreed to a unanimous correspondence for the publication of the manuscript.

Acknowledgments: The authors acknowledge the data centers, namely: The Climatic Research Unit (CRU) and World Climate Research Program (WCRP) Working Group on Coupled Models (WGCM) for availing the observed and latest outputs from Coupled Model Intercomparison Project (CMIP) phase six. Excellent research facilities provided by Nanjing University of Information Science and Technology (NUIST) are greatly appreciated.

\section{References}

Adhikari, U., Nejadhashemi, A.P., Woznicki, S.A., 2015. Climate change and Eastern Africa. a review of impact on major crops. Food Energ. Secur., 4: 110-132. doi:10.1002/fes3.61

Ahmad, I., Tang, D., Wang, T., Wang, M., Wagan, B., 2015. Precipitation trends over time using Mann-Kendall and spearman's Rho tests in swat river basin, Pakistan. Advances in Meteorology. https://doi.org/10.1155/2015/431860

Ahmed, K., Sachindra, D.A., Shahid, S., Demirel, M.C., Chung, E. S., 2019. Selection of multimodel ensemble of general circulation models for the simulation of precipitation and maximum and minimum temperature based on spatial assessment metrics. Hydrol. Earth Syst. Sci. 23, 4803-4824. https://doi.org/10.5194/hess-23-4803-2019

Akinsanola, A.A., Zhou, W., 2019. Projections of West African summer monsoon rainfall 
extremes from two CORDEX models. Clim. Dyn. 52 2017.dio. 10.1088/1748/17489326/ab92cl

Ali, S., Eum, H.-I., Jaepil, C., Li, D., Khan, F., Dairaku, K., Shrestha, M. L., Hwang, S., Naseem, W., Khan, I. A., Fahad, S., 2019. Assessment of climate extremes in future projections downscaled by multiple statistical downscaling methods over Pakistan. Atmospheric Research, 222, 114-133. https://doi.org/10.1016/J.ATMOSRES.2019.02.009

Almazroui, M., Islam, M.N., Saeed, S., Saeed, F., Ismail, M., 2020c. Future Changes in Climate over Arabian Peninsula based on CMIP6 Multimodel Simulations. Earth Systm Environ. https://dio.org/10.1007/s41748-020-00183-5

Almazroui, M., Saeed, F., Saeed, S., Nazrul Islam, M., Ismail, M., Klutse, N. A. B., Siddiqui, M. H. 2020a. Projected Change in Temperature and Precipitation Over Africa from CMIP6. Earth Systm Environ. https://doi.org/10.1007/s41748-020-00161-X

Almazroui, M., Saeed, S., Saeed, F., Islam, M.N., Ismail, M., 2020b. Projections of Precipitation and Temperature over the South Asian Countries in CMIP6. Earth Systm Environ. https://doi.org/10.1007/s41748-020-00157-7

Anyah, R.O, Semazzi, F.H.M., Xie, L., 2006. Simulated physical mechanisms associated with climate variability over Lake Victoria in East Africa. Mon. Weather. Rev., 134: 3588-3609. doi:10.1175/MWR3266.1

Ayugi, B. O., Tan, G., Ongoma, V., Mafuru, K. B., 2018. Circulations Associated with Variations in Boreal Spring Rainfall over Kenya. Earth Syst Environ. 2, 421-434. https://doi.org/10.1007/s41748-018-0074-6

Ayugi, B., Dike, V., Ngoma, H.N., Babaousmail, H., Ongoma, V., 2021. Future Changes in Precipitation Extrems over East Africa based on CMIP6 Projections. Preprints. https://dio.10.20944/preprints202101.0112.v1

Ayugi, B., Tan, G., Gnitou, G.T., Ojara, M., Ongoma, V., 2020b. Historical evaluations and simulations of precipitation over Eastern Africa from Rossby Centre Regional Climate Model. Atmos. Res. 232. https://dio.org/10.1016.jatmosres.2019.104705

Ayugi, B., Tan, G., Niu, R., Dong, Z., Ojara, M., Mumo, L., Hassen, B., Ongoma, V., 2020a. Evaluation of meteorological droughts and wet scenarios over Kenya, East Africa. Atmosphere 2020, 11, 307. https://dio.org/10.3390/atmos11030307

Ayugi, B.O., Tan, G., 2019. Recent trends of surface air temperatures over Kenya from 1971 to 2010. Meteorol. Atmos. Phys.,131, 1401-1413 https://doi.org/10.1007/s00703-018-0644-z

Ayugi, B.O., Wen, W., Chepkemoi, D., 2016. Analysis of Spatial and Temporal Patterns of Rainfall Variations over Kenya. J. Environ. Earth Sci, 6(11).

Babaousmail, H., Hou, R., Ayugi, B., Tchalim, G., 2019. Journal of Atmospheric and SolarTerrestrial Physics Evaluation of satellite-based precipitation estimates over Algeria during $1998 \quad-\quad 2016 . \quad$ J. Atmos. Solar-Terrestrial Phys. 195, 105139. https://doi.org/10.1016/j.jastp.2019.105139

Bell, J. P., Tompkins, A. M., Bouka-Biona, C., Sanda, I. S., 2015. A process-based investigation into the impact of the Congo basin deforestation on surface climate. J. Geophys. Res. Atmos, 120, 5721-5739. https: dio. 10.1002/2014JD022586

Brunner, L., Pendergrass, A., Lehner, F., Merrifield, A., Lorenz, R., Knutti, R., 2020. Reduced global warming from CMIP6 projections when weighting models by performance and independence. Earth Syst. Dyn. Discuss. 6, 1-23. https://doi.org/10.5194/esd-2020-23

Camberlin P, Philippon N (2002) The East African March - May Rainy Season: Associated 
Atmospheric Dynamics and Predictability over the 1968 - 97. Period J Climate 15: 10021019. doi.org/10.1175/1520-0442(2002)015\%3C1002: TEAMMR\%3E2.0.CO;2

Camberlin, P., 2018. Climate of Eastern Africa (Vol. 1). https://doi.org/10.1093/acrefore/9780190228620.013.512

Collins, J.M., 2011. Temperature variability over Africa. J. Climate 24: 3649-3666. https://doi:10.1175/2011JCLI3753.1

Dai, A., 2016. Future Warming Patterns Linked to Today's Climate Variability. Sci Rep,6, 6-11. https://doi.org/10.1038/srep19110

Daron, J.D., 2014. Regional Climate Messages: East Africa. Scientific report from the CARIAA Adaptation at Scale in Semi-Arid Regions (ASSAR) Project, December 2014.

Dosio, A., Mentaschi, L., Fischer, E. M., Wyser, K., 2018. Extreme heat waves under $1.5^{\circ} \mathrm{c}$ and $2{ }^{\circ} \mathrm{c}$ global warming. Environ. Res. Lett. 13,054006. https: dio.org/10.1088/1748-9326/aab827

Duan, A., Hu, J., Xiao, Z. 2013. The Tibetan Plateau summer monsoon in the CMIP5 simulations. J. Climate, 26, 7747-7766.Dio. 10.1175/JCL-D-12-00685.1

Eyring, V., Bony, S., Meehl, G.A., Senior, C.A., Stevens, B., Stouffer, R.J., Taylor, K.E., 2016. Overview of the coupled model Intercomparison project phase 6 (CMIP6) experimental design and organization. Geosci. Model Dev. (GMD) 9, 1937-1958. https://doi.org/10.5194/gmd-9-1937-2016.

Eyring, V., Cox, P.M., Flato, G.M., Gleckler, P.J., Abramowitz, G., Caldwell, P., Collins, W.D., Gier, B.K., Hall, A.D., Hoffman, F.M., Hurtt, G.C., Jahn, A., Jones, C.D., Klein, S.A., Krasting, J.P., Kwiatkowski, L., Lorenz, R., Maloney, E., Meehl, G.A., Pendergrass, A.G., Pincus, R., Ruane, A.C., Russell, J.L., Sanderson, B.M., Santer, B.D., Sherwood, S.C., Simpson, I.R., Stouffer, R.J., Williamson, M.S., 2019. Taking climate model evaluation to the next level. Nat. Clim. Chang. 9, 102-110. https://doi.org/10.1038/s41558-018-0355-y

Fan, X., Duan, Q., Shen, C., Wu, Y., Xing, C., 2020. Global surface air temperatures in CMIP6: Historical performance and future. Environ. Res. Lett. https://doi.org/10.1088/17489326/abb051

FAO., 2019. The state of Food Security and Nutrition in the World 2019. Safeguarding against economic slowdowns and downturns. Rome, FAO. Licence: CC BY-NC-SA. 3.0 IGO

Flato, G., Coauthors., 2013. Evaluation of climate models. Climate Change 2013: The Physical Science Basis. Contribution of Working Group I to the Fifth Assessment Report ofthe Intergovernmental Panel on Climate Change, T. F.Stocker et al., Eds., Cambridge University Press, 741-866,https://doi.org/10.1017/CBO9781107415324.020

Forster, P.M., Maycock, A.C., McKenna, C.M., Smith, C.J., 2020. Latest climate models confirm need for urgent mitigation. Nat. Clim. Chang. 10, 7-10. https://doi.org/10.1038/s41558-0190660-0

Friedman, A.R., Hwang, Y.T., Chiang, J.C.H., Frierson, D.M.W., 2013. Interhemispheric temperature asymmetry over the twentieth century and in future projections. Journal of Climate. https://doi.org/10.1175/JCLI-D-12-00525.1

Gbobaniyi, E., Sarr, A., Sylla, M.B., Diallo, I., Lennard, C., Dosio, A., Dhiediou., Kamga, A., Klutse, N.A.B., Hewitson, B., Nikulin, G., Lamptey, B., 2013. Climatology, annual cycle and interannual variability of precipitation and temperature in CORDEX simulations over West Africa. Int. J. Climatol. 34, 2241-2257. https://doi:10.1002/joc.3834

Gebrechorkos, S.H., Hülsmann, S., Bernhofer, C., 2018. Evaluation of Multiple Climate Data Sources for Managing Environmental Resources in East Africa. Hydro. Earth Syst. Sci., 22, 4547-4564. https://doi.org/10.5194/hess-2017-558 
Gebremeskel, G., Tang, Q., Sun, S., Huang, Z., Zhang, X., Liu, X., 2019. Droughts in East Africa: Causes, impacts and resilience. Earth-Sci Rev, 193, 146-161. https://doi.org/10.1016/j.earscirev.2019.04.015

Griffiths, J.F., 1972. Eastern Africa. In H. Landsberg (Ed.), Climates of Africa: World Survey of Climatology (Vol. 10, pp. 313-332). Amsterdam: Elsevier, Amsterdam, Vol. 10, pp.313-338.

Grose, M. R., Narsey, S., Delage, F. P., Dowdy, A. J., Bador, M., Boschat, G., Lyu, K., 2020. Insights from CMIP6 for ' 'Australia's future climate.' 'Earth's Future, 8, e2019EF001469.

Gu, G., Adler, R.F., 2013. Interdecadal variability/long-term changes in global precipitation patterns during the past three decades: Global warming and/or pacific decadal variability? Clim Dyn, 40, 3009-3022. https://doi.org/10.1007/s00382-012-1443-8

Gusain, A., Ghosh, S., Karmakar, S., 2020. Added value of CMIP6 over CMIP5 models in simulating Indian summer monsoon rainfall. Atmospheric Research, 232, 104680.

Haile, G.G., Tang, Q., Hosseini-Moghari, S.M., Liu, X., Gebremicael, T.G., Leng, G., Kebde, A., Yun, X. Projected impacts of climate change on drought patterns over East Africa. ' 'Earth's Future, https://doi.org/10.11029/2020EF001502

Hajima, T., Watanabe, M., Yamamoto, A., Tatebe, H., Noguchi, M. A., Abe, M., Ito, A., 2020. Development of the MIROC-ES2L Earth system model and the evaluation of biogeochemical processes and feedbacks. Geosci. Model Dev., 13(5), 2197-2244. Dio.org/10.5194/gmd-132197-2020

Hamed, K.H., Rao, R.A., 1998. A modified Mann-Kendall trend test for autocorrelated data. J Hydrol 204:182-196

Harris, G.R., Sexton, D.M.H., Booth, B.B.B., Collins, M., Murphy, J.M., Webb, M.J., 2006. Frequency distributions of transient regional climate change from perturbed physics ensembles of general circulation model simulations. Clim. Dyn https://doi.org/10.1007/s00382-006-0142-8

Harris, I., Jones, P.D., Osborn, T.J., Lister, D.H., 2014. Updated high-resolution grids of monthly climatic observations - the CRU TS3.10 Dataset. Int. J. Climatol.,34: 623-642. https://doi.org/10.1002/joc.3711

Harris, I., Osborn, T.J., Jones, P., Lister, D. Version 4 of the CRU TS monthly high-resolution gridded multivariate climate dataset. Sci Data 7, 109 (2020). https://doi.org/10.1038/s41597020-0453-3

Hausfather, Z., 2019. CMIP6: the next generation of climate models explained. https://www.carbonbrief.org/cmip6-the-next-generation-of-climate-models-explained. Accessed on 2021.01.11

Hua, W., Zhou, L., Chen, H., Nicholson, S.E., Raghavendra, A., Jiang, Y., 2016. Possible causes of the Central Equatorial African long-term drought. Environ. Res. Lett. 11 (12), 124002.

Huang, J., Li, Y., Fu, C., Chen, F., Fu, Q., Dai, A., Wang, G., 2017. Dryland climate change: Recent progress and challenges. Rev. Geophys, 55, 719-778. https://doi.org/10.1002/2016RG000550

IPCC, 2014. Climate Change 2014: Synthesis Report. Contribution of Working Groups I, II and III to the Fifth Assessment Report of the Intergovernmental Panel on Climate Change [Pachauri RK, Meyer LA (eds.)]. IPCC, Geneva, Switzerland, 151 pp.

IPCC., 2001. Climate Change 2001: The Scientific Basis. Contribution of Working Group I to the Third Assessment Report of the Intergovernmental Panel on Climate Change [Houghton JT, et al. (eds.)]. Cambridge University Press, Cambridge, United Kingdom and New York, NY, 
USA, $881 \mathrm{pp}$.

IPCC., 2018. Global Warming of $1.5^{\circ} \mathrm{C}$ : An IPCC Special Report on the Impacts of Global Warming of $1.5^{\circ} \mathrm{C}$ Above Pre-Industrial Levels and Related Global Greenhouse Gas Emission Pathways, in the Context of Strengthening the Global Response to the Threat of Climate Change, Sustainable Development, and Efforts to Eradicate Poverty. Intergovernmental Panel on Climate Change.

Iqbal, W., Zahid, M., 2014a. Historical and Future Trends of Summer Mean Air Temperature over South Asia. Pakistan J. Meteorol. 10, 67-74.

Iyakaremye, V., Zeng, G., Zhang, G., 2020. Changes in extreme temperature events over Africa under $1.5^{\circ} \mathrm{C}$ and $2.0^{\circ} \mathrm{C}$ global warming scenario Int. J Climatol. Dio: 10.1002/joc.6868

Jiang, D., Hu, D., Tian, Z., Lang, X., 2020. Differences between CMIP6 and CMIP5 Models in Simulating Climate over China and the East Asian Monsoon. Adv. Atmos. Sci, 37, 11021118.https://doi.org/10.1007/s00376-020-2034-y

Juma, B., Olang, L.O., Hassan, M., Chasia, S., Bukachi, V., Shiundu, P., Mulligan, J., 2020. Analysis of rainfall extremes in the Ngong River Basin of Kenya: Towards integrated urban flood risk management. Phys. Chem. Earth, https: dio.org/10.1016/j.pce.2020.102929

Karim, R., Tan, G., Ayugi, B., Babaousmail, H., Liu, F., 2020. Evaluation of Historical CMIP6 Model Simulations of Seasonal Mean Temperature over Pakistan during 1970-2014. Atmosphere (Basel). 11, 1005. https://doi.org/10.3390/atmos11091005

Karim, R., Tan, G., Ayugi, B., Babaousmail, H., Liu, F., Ngoma, H., Ongoma, V., 2021. Future changes in seasonal temperature over Pakistan in CMIP6 Atmos. Res. (Under Review).

Kendall, M.G.,1975. Rank Correlation Methods, $4^{\text {th }}$ ed. Griffin, London, 202 pp.

Kerandi, N., Laux, P., Arnault, J., Kunsatmann, H., 2017. Performance of the WRF model to simulate the seasonal and interannual variability of hydrometeorological variables on East Africa: a cas study for the Tana Rver basin in Kenya. Theor Appl Climatol 130: 401-418 .https://doi.org/10.1007/s00704-016-1890-y

Kharin, V., Flato, G.M., Gillett, N.P., Zwiers, F., Anderson, K.J., 2018. Risks from Climate Extremes Change Differently from $1.5^{\circ} \mathrm{C}$ to $2.0^{\circ} \mathrm{C}$ Depending on Rarity. Earth's Future, 6, 704-715, doi:10.1002/2018ef000813

Kilavi, M., MacLeod, D., Ambani, M., Robbins, J., Dankers, R., Graham, R., Helen, T., Salih, A. A. M., Todd, M.C., 2018. Extreme rainfall and flooding over Central Kenya Including Nairobi City during the long-rains season 2018: causes, predictability, and potential for early warning and actions Atmosphere 9, 472. Dio. 10.3390/atmos9120472

Kim, J., Ivanov, V. Y., Fatichi, S., 2015. Climate change and uncertainty assessment over a hydroclimatic transect of Michigan, Stoch. Environ. Res. Risk Assess., 30, 923-944. https// dio.org/10.1007/s00477-015-1097-2

Kumar, P., Sarthi, P.P., 2019. Surface Temperature Evaluation and Future Projections Over India Using CMIP5 Models. Pure and Applied Geophysics, 176(11), 5177-5201. https://doi.org/10.1007/s00024-019-02203-6

Lehner, F., Coats, S., Stocker, T.F., Pendergrass, A.G., Sanderson, B., Raible, C.C., Smerdon, J. E., 2017. Projected drought risk in $1.5^{\circ} \mathrm{C}$ and $2{ }^{\circ} \mathrm{C}$ warmer climates. Geophysical Research Letters, 44(14), 7419-7428. https://doi.org/10.1002/2017GL074117

Libanda, B., Ngonga, C., 2018. Projection of frequency and intensity of extreme precipitation in Zambia: a CMIP5 study. Clim Res 76:59-72. https: dio.org/10.3354/cr01528

Liebmann, B., Hoerling, M.P., Funk, C., Bladé, I., Dole, R.M., Allured, D., Quan, X., Pegion, P., Eischeid, J.K., 2014. Understanding Recent Eastern Horn of Africa Rainfall Variability and 
Change. J. Climate,27: 8630-8645. doi:10.1175/JCLI-D-13-00714.1

Luo, N., Guo, Y.,Gao, Z., Chen, K., Chou, J., 2020. Assessment of CMIP6 and CMIP5 model performance for extreme temperature in China,Atmospheric and Oceanic Science Letters, DOI: $10.1080 / 16742834.2020 .1808430$

Lyon, B., 2014. Seasonal drought in the Greater Horn of Africa and its recent increase during the March-May long rains. J. Clim. 27 (21), 7953-7975.

Malhi, Y., Adu-Bredu, S., Asare, R. A., Lewis, S. L., Mayaux, P., 2013. African rainforests: past, $\begin{array}{lllll}\text { present and future.Phil Trans } R \text { Soc } & B \quad 368, \quad 20312 .\end{array}$ http://dx.dio.org/10.1098/rstb.2012.0312

Mallika, M., Sundaram, S.M., Nirmala, M., 2015. Annual mean temperature prediction of India using K-Nearest Neighbour technique. Appl. Math. Sci. 9, 613-616. https://doi.org/10.12988/ams.2015.411953

Mann, H.B., 1945. Non-parametric tests against trend. Econometrica 13: 245-259. https://doi.org/10.2307/1907187

Mauritsen T, Bader J, Becker T, et al. 2019. Developments in the MPI-M Earth System Model version 1.2 (MPI-ESM1.2) and its response to increasing $\mathrm{CO}_{2}$. J Adv Mod Ear Syst 2019; 11 : 998-1038.https//dio.org/10.1029/2018MS001400

Miao, C., Duan, Q., Sun, Q., Huang, Y., Kong, D., Yang, T., Ye, A., Di, Z., Gong, W., 2014. Assessment of CMIP5 climate models and projected temperature changes over Northern Eurasia. Environ. Res. Lett., 9, 055007. https/dio.1088/1748-9326/9/5/055007

Moseid, K. O., Schulz, M., Storelvmo, T., Julsrud, I. R., Olivié, D., Nabat, P., Takemura, T., 2020. Bias in CMIP6 models compared to observed regional dimming and brightening trends (1961-2014). Atmospheric Chem. Phys.https://dio.org/10.5194/acp-2019-1210

Mumo, L., Yu, J., Ayugi, B., 2019. Evaluation of spatiotemporal variability of rainfall over Kenya from 1979 to 2017. J. Atmospheric Sol-Terr Phys, 194, 105097. https://doi.org/10.1016/j.jastp.2019.105097.

Mumo, L., Yu, J., Fang, K., 2018. Assessing Impacts of Seasonal Climate Variability on Maize Yield in Kenya. Int. J. Plant Prod, 1-13. https://doi.org/10.1007/s42106-018-0027-X

Mumo, L., Yu, J.,2020. Gauging the performance of CMIP5 historical simulation in reproducing observed gauge rainfall over Kenya. Atmos Res. 236 (2020): 104808 https://doi.org/10.1016/j.atmosres.2019.104808

Ngoma, H., Wen, W., Ayugi, B., Babaousmail, H., Karim, R., Ongoma, V., 2021b. Evaluation of the Global Climate Models in CMIP6 over Uganda. Int. J. Climatol. Under press

Ngoma, H., Wen, W., Ojara, M., Ayugi, B., 2021a. Assessing current and future spatiotemporal precipitation variability and trends over Uganda, East Africa based on CHIRPS and Regional Climate Models Datasets. Meteorol. Atmospheric Phys. Under press

Niang, I., Ruppel, O.C., Abdrabo, M.A., Essel, A., Lennard, C., Padgham, J., Urquhart, P., 2014. Africa. In: Climate Change 2014: Impacts, Adaptation, and Vulnerability. Part B: Regional Aspects. Contribution of Working Group II to the Fifth Assessment Report of the Intergovernmental Panel on Climate Change [Barros VR, Field CB, Dokken DJ, Mastrandrea MD, Mach KJ, Bilir TE, Chatterjee M, Ebi KL, Estrada YO, Genova RC, Girma B, Kissel ES, Levy AN, MacCracken S, Mastrandrea PR, White LL (eds.)]. Cambridge University Press, Cambridge, United Kingdom and New York, NY, USA, 1199-1265 pp.

Nicholson, S.E., 2014. A detailed look at the recent drought situation in the Greater Horn of Africa. J. Arid Environ. 103, 71-79. https://doi.org/10.1016/jaridenv.2013.12.003

Nie, Y., Li, L.J., Tang, Y.L., Wang, B., 2019. Impacts of changes of external forcings from CMIP5 
to CMIP6 on surface temperature in FGOALS-g2. Sola, 15, 211-215, https://doi.org/10.2151/sola.2019-038.

Nogherotto, R., Coppola, E., Giorgi, F., Mariotti, L., 2013. Impact of Congo Basin deforestation on the African monsoon. Atmos. Sci. Lett., 14, 45-51. DOI: 10.1002/as12.416

O’Neill, B.C., Tebaldi, C., Vuuren, D.V., Erying, V., Fridelingstein, Hurtt, G., Knutti, R., Kriegler, E., Lamarque, J.F., Lowe, J., Meehl, J., Moss, R., Riahi, K., Sanderson, B.M., 2017. The roads ahead: Narratives for shared socioeconomic pathways describing world futures in the $21^{\text {st }} \quad$ century. Global Environ. Chang., 42, 169-180. https://doi.org/10.1016/j.gloenvcha.2015.01.004

Odada, E.O. Olago, D., Olaka, L.A., 2020. An East African perspective of Anthropocene. Scientific African. https://dio.org/10.1016/j.sciaf.2020.e00553

Ogallo, L.A., 1993. Dynamics of the East African climate. Proc. Indian Acad. Sci. - Earth Planet Sci., 102: 203-217. doi:10.1007/BF02839191

Ogega, O.M., Koske, J., Kung'u, J.B., Scoccimarro, E., Endris, H.S., Mistry, M., 2020. Heavy precipitation events over East Africa in a changing climate: results from CORDEX RCMs. Clim. Dyn. 2020. doi.org/10.1007/s00382-020-05309-z.

Ogwang, B.A., Chen, H., Tan, G., Ongoma, V., Ntwali, D., 2015b. Diagnosis of East African climate and the circulation mechanisms associated with extreme wet and dry events: a study based on RegCM4. Arab J Geosci 8: 10255-10265. https://doi.org/10.1007/s12517-0151949-z

Omondi, P.A., Awange, J.L., Forootan, E., Ogallo, L.A., Barakiza, R., Girmaw, G.B., Fesseha, I., Kululetera, V., Kilembe, C., Mbati, M.M., Kilavi, M., 'King'uyu S.M., Omeny, P.A., Njogu, A., Badr, E.M., Musa, T.A., Muchiri, P., Bamanya, D., Komutunga, E., 2014. Changes in temperature and precipitation extremes over the Greater Horn of Africa region from 1961 to 2010. Int J Climatol 34: 1262-1277. http://doi.org/10.1002/joc.3763.

Omumbo, J.A., Lyon, B., Waweru, S.M., Connor, S.J., Thomson, M.C., 2011 Raised temperatures over the Kericho tea estates: revisiting the climate in the East African highlands malaria debate. Malar J 10: 12. http://doi.org/10.1186/1475-2875-10-12

''O'Neill, B. C., Coauthors., 2016. The scenario model intercomparison project (ScenarioMIP) for CMIP6. Geoscientific Model Development, 9, 3461-3482.

Ongoma, V., Chen, H., 2017. Temporal and spatial variability of temperature and precipitation over East Africa from 1951 to 2010. Meteorol. Atmos. Phys. 129(2) 131144.https://doi.org/10.1007/s00703-016-0462-0

Ongoma, V., Chen, H., Gao, C., 2018a. Projected Change in Mean Rainfall and Temperature over East Africa based on CMIP5 Models. Int. J. Climatol. 38: 1375-1392 https://doi.org/10.1002/joc.5252

Ongoma, V., Chen, H., Gao, C., 2019. Evaluation of CMIP5 twentieth century rainfall simulation over the equatorial East Africa. Theor. Appl. Climatol. 135 (3-4), 893910.http://doi.org/10.1007/s00704-018-2392-x

Ongoma, V., Chen, H., Gao, C., Nyongesa, A.M., Polong, F., 2018b. Future changes in Climate Extreme over Equatorial East Africa based on CMIP5 multimodel ensemble. Nat Haz, 90, 901-920.doi.org/10.1007/s11069-017-3079-9

Ongoma, V., Mohammed, A.R., Ayugi, B., Nisha, F., Galvin, S., Shilije, Z.W., Ogwang, B.A., 2020. Variability of dirnual temperature range over Pacific Island countries, a case of Fiji. Meteorol. Atmos. Phys. https://doi.org/10.1007/s00703-020-00743-4

Onyutha, C., 2020. Analyses of rainfall extremes in East Africa based on observations from rain 
gauges and climate change simulations by CORDEX RCMs. ClimDyn (2020). https://doi.org/10.1007/s00382-020-05264-9

Osima, S., Indasi, V.S., Zaroug, M., Endris, H.S., Gudoshava, M., Misiani, H.O., Dosio, A., 2018. Projected Climate over Greater Horn of Africa under $1.5^{\circ} \mathrm{C}$ and $2{ }^{\circ} \mathrm{C}$ global warming. Environ. Res. Lett.13, 6. https://doi.org/10.1128/JVI.74.13.6223-6226.2000

Otieno, V.O., Anyah, R.O. 2013a. CMIP5 simulated climate conditions of the Greater Horn of Africa (GHA). Part 1: Contemporary climate. Clim. Dyn.,41: 2081-2097. doi:10.1007/s00382-012-1549-z

Otieno, V.O., Anyah, R.O. 2013b. CMIP5 simulated climate conditions of the Greater Horn of Africa (GHA). Part II: Projected climate. Clim. Dyn.,41: 2099-2113. doi:10.1007/s00382013-1694-Z

Palmer, T.N., Shutts, G.J., Hagedorn, R., Doblas-Reyes, F.J., Jung, T., Leutbecher, M., 2005. Representing model uncertainty in weather and climate prediction. Annu. Rev. Earth Planet. Sci. https://doi.org/10.1146/annurev.earth.33.092203.122552

Parsons, L.A., Brennan, M.K., Wills, R.C.J., Proistosescu, C., 2020. Magnitudes and Spatial Patterns of Interdecadal Temperature Variability in CMIP6. Geophys. Res. Lett. https://doi.org/10.1029/2019GL086588

Pepin, N. C., Duane, W. J., Schaefer, M., Pike, G., Hardy, D. R., 2014. Measuring and modeling the retreat of the summit ice fields on Kilimanjaro, East Africa. Arctic, Antarctic, and Alpine Research, 46(4), 905-917. https://org/10.1657/1938-4246-46.4.905

Pincus, R., Batstone, C. P., Patrick Hofmann, R. J., Taylor, K. E., Glecker, P. J., 2008. Evaluating the present-day simulation of clouds, precipitation, and radiation in climate models. J.Geophys. Res. Atmos. 113, D14209. https://doi.org/10.1029/2007JD009334.

Riahi, K., Coauthors., 2017. The shared socioeconomic pathways and their energy, land use, and greenhouse gas emissions implications: An overview. Global Environ. Change, 42, 153-168, https://doi.org/10.1016/j.gloenvcha.2016.05.009.

Rosenzweig, C., Elliott, J., Deryng, D., Ruane, A.C., Müller, C., Arneth, A., 2014. Assessing agricultural risks of climate change in the $21^{\text {st }}$ century in a global gridded crop model intercomparison. Proc Natl Acad Sci USA 111: 4-9. https://doi.org/10.1073/pnas.1222463110

Sen, P.K., 1968. Estimates of the Regression Coefficient based on Kendall's Tau. J. Amer. Stat. Assoc.,63: 1379-1389. doi:10.2307/2285891

Seneviratne, S. I., Hauser, M., 2020. Regional Climate Sensitivity of Climate Extremes in CMIP6 Versus CMIP5 Multimodel Ensembles. 'Earth's future, 8, e2019EF001474

Seneviratne, S.I., Nicholls, N., Easterling, D., Goodess, C.M., Kanae, S., Kossin, J., Luo, Y., Marengo, J., McInnes, K., Rahimi, M., Reichstein, M., Sorteberg, A., Vera, C., Zhang, X., 2012. Changes in climate extremes and their impacts on the natural physical environment. In: Managing the Risks of Extreme Events and Disasters to Advance Climate Change Adaptation. A Special Report of Working Groups I and II of the Intergovernmental Panel on Climate Change [Field CB, Barros V, Stocker TF, Qin D, Dokken DJ, Ebi KL, Mastrandrea MD, Mach KJ, Plattner G-K, Allen SK, Tignor M, Midgley PM (eds.)]. Cambridge University Press, Cambridge, UK and New York, NY, USA, pp. 109 -230.

Shi, C., Jiang, Z., Chen, W. Li, L., 2018. Changes in temperature extremes over China under 1.5 ${ }^{\circ} \mathrm{C}$ and $2{ }^{\circ} \mathrm{C}$ global warming targets. Adv. Climate Change Res. 9, 120-129.

Shongwe, M.E, Van Oldenborgh, G.J, Van den Hurk, B, Van Aalst M., 2011. Projected changes in mean and extreme precipitation in Africa under global warming. Part II: East Africa. J 
Climate 24: 3718-3733. http://doi.org/10.1175/2010JCLI2883.1.

Siddique, M.A., Dongyun, L., Li, P., Rasool, U., Khan, T.U., Farooqi, T.J.A., Wang, L., Fan, B., Rasool, M.A., 2020. Assessment and simulation of land use and land cover change impacts on the land surface temperature of Chaoyang District in Beijing, China. Peer J. https://doi.org/10.7717/peerj.9115

Sillmann, J.V., Kharin, V., Zhang, X.W., Zwiers, F., Bronaugh, D., 2013. Climate extremes indices in the CMIP5 multimodel ensemble: Part 2. Future climate projections. J. Geophys. Res., 118: 2473-2493. doi:10.1002/jgrd.50188.

Steffen, W., Rockström, J., Richardson, K., Lenton, T. M., Folke, C., Liverman, D., Summerhayes, C.P., Barnosky, A.D., Cornell, S.E., Crucifix, M., Donges, J.F., Fetzer, I., Lade, S.J., Scheffer, M., Winkelmann, R., Schellnhuber, H. J., 2018. Trajectories of the Earth System in the Anthropocene. PNAS, 115, 8252-8259. dio/10.1073/pnas.181014115

Sylla, M.B., Diallo, I., Pal, J.S., 2013. West African monsoon in state-of the-art regional climate models, In Climate Variability-Regional and Thematic Patterns Tarhule A (ed) ISBN: 980953-307-816-3

Tadeyo, E., Chen, D., Ayugi, B., Yao, C., 2020. Characterization of Spatio-Temporal Trends and Periodicity of Precipitation over Malawi during 1979 - 2015. Atmosphere. https://doi.org/10.3390/atmos11090891

Tan, G., Ayugi, B., Ngoma, H., Ongoma, V., 2020. Projections of Future Meteorological Drought Events under representative concentrations pathways (RCPs) of CMIP5 over Kenya, East Africa. Atmos Res. https://doi.org/10.1016/j.atmosres.2020.105112

Taylor, K. E., 2001. in a Single Diagram. J. Geophys. Res, 106, 7183-7192. https://doi.org/10.1029/2000JD900719

Tokarska, K.B., Stolpe, M.B., Sippel, S., Fischer, E.M., Smith, C.J., Lehner, F., Knutti, R., 2020. Past warming trend constrains future warming in CMIP6 models. Sci. Adv. 6. https://doi.org/10.1126/sciadv.aaz9549

UNFCCC: United nations framework convention on climate change., 2015. Decision 1/cp.21. The Paris agreement. [Available online at http://unfccc.int/resource/docs/2015/cop21/eng/109r01.pdf].

van Vuuren, D. P., and Coauthors, 2011. The representative concentration pathways: An overview. Climatic Change, 109,5-31, https://doi.org/10.1007/s10584-011-0148-z.

Vermeulen, J.L., Hillebrand, A., Geraerts, R., 2017. A comparative study of k-nearest neighbour techniques in crowd simulation. Comput. Animat. Virtual Worlds 28. https://doi.org/10.1002/cav.1775

Voldoire, A., Saint-Martin, D., Sénési, S., Decharme, B., Alias, A., Chevallier, M., Colin, J., Guérémy, J. F., Michou, M., Moine, M. P., Nabat, P., Roehrig, R., Salas y Mélia, D., Séférian, R., Valcke, S., Beau, I., Belamari, S., Berthet, S., Cassou, C., Cattiaux, J., Deshayes, J., Douville, H., Ethé, C., Franchistéguy, L., Geoffroy, O., Lévy, C., Madec, G., Meurdesoif, Y., Msadek, R., Ribes, A., Sanchez-Gomez, E., Terray, L., Waldman, R., 2019. Evaluation of CMIP6 DECK experiments with CNRM-CM6-1. J Adv Model Earth Syst., 11, 2177- 2213. Dio.org/10.1029/2019MS001683

Walther, G., Post, E., Convey, P., Menzel, A., Parmesan, C., Beebee, T.J., Bairlein, C.F., 2002 Ecological response to recent climate change. Nature 416: 389-395.

WMO., 2020. WMO Provisional Report on the State of the Global climate 2020

World Bank, 2012. Doing business in the East African economies.IFC/World Bank Rep., 116

Wyser, K., Kjellström, E., Koenigk, T., Martins, H., Döscher, R., 2020. Warmer climate 
projections in EC-Earth3-Veg: The role of changes in the greenhouse gas concentrations from CMIP5 to CMIP6. Environ. Res. Lett. https://doi.org/10.1088/1748-9326/ab81c2

Xin, X., Wu, T., Zhang, J., Yao, J., Fang, Y., 2020. Comparison of CMIP6 and CMIP5simulations of precipitation in China and the EastAsian summer monsoon. Int J Climatol. 2020;118.https://doi.org/10.1002/joc.6590

Zamani, Y., Monfared, S.A.H., Hamidianpour, M., 2020. A comparison of CMIP6 and CMIP5 projections for precipitation to observational data: the case of Northeastern Iran. Theor Appl Climatol. 142, 1613-1623.https://dio.org/10.1007/s00704-020-03406-X.

Zelinka, M.D., Myers, T.A., McCoy, D.T., Po-Chedley, S., Caldwell, P.M., Ceppi, P., Klein, S.A., Taylor, K.E., 2020. Causes of Higher Climate Sensitivity in CMIP6 Models. Geophys. Res. Lett. 47. https://doi.org/10.1029/2019GL085782

Zhu, H.H., Jiang, Z.H., LI, J., Li, W., Sun, C.X., Li, L., 2020. Does CMIP6 inspire more confidence in simulating climate extremes over China? Adv. Atmos. Sci., 37, 1119-1132, https://doi.org/10.1007/s00376-020-9289-1.

Zhu, Y. Y., Yang, S., 2020. Evaluation of CMIP6 for historical temperature and precipitation over the Tibetan Plateau and its comparison with CMIP5. Adv. Clim. Change Res. https://dio.org/10.1016/j.accre.2020.08.001 